\title{
Set-up of the PMIP3 paleoclimate experiments conducted using an Earth system model, MIROC-ESM
}

\author{
T. Sueyoshi ${ }^{1}$, R. Ohgaito ${ }^{1}$, A. Yamamoto ${ }^{2}$, M. O. Chikamoto ${ }^{3}$, T. Hajima ${ }^{1}$, H. Okajima ${ }^{2}$, M. Yoshimori ${ }^{2}$, M. Abe ${ }^{4}$, \\ R. O'ishi ${ }^{2}$, F. Saito ${ }^{1}$, S. Watanabe ${ }^{1}$, M. Kawamiya ${ }^{1}$, and A. Abe-Ouchi ${ }^{1,2}$ \\ ${ }^{1}$ Japan Agency for Marine-Earth Science and Technology, 3173-25, Showa-machi Kanazawa-ku, Yokohama City, 236-0001, \\ Japan \\ ${ }^{2}$ Atmosphere and Ocean Research Institute, University of Tokyo, Japan \\ ${ }^{3}$ International Pacific Research Center, Pacific Ocean Science and Technology Bldg., 1680 East-West Road, University of \\ Hawaii, Honolulu, Hawaii 96822, USA \\ ${ }^{4}$ National Institute for Environmental Studies, 16-2 Onogawa, Tsukuba-City, Ibaraki, 305-8506, Japan
}

Correspondence to: T. Sueyoshi (sue@jamstec.go.jp)

Received: 27 July 2012 - Published in Geosci. Model Dev. Discuss.: 3 September 2012

Revised: 22 April 2013 - Accepted: 23 April 2013 - Published: 21 June 2013

\begin{abstract}
Paleoclimate experiments using contemporary climate models are an effective measure to evaluate climate models. In recent years, Earth system models (ESMs) were developed to investigate carbon cycle climate feedbacks, as well as to project the future climate. Paleoclimate events can be suitable benchmarks to evaluate ESMs. The variation in aerosols associated with the volcanic eruptions provide a clear signal in forcing, which can be a good test to check the response of a climate model to the radiation changes. The variations in atmospheric $\mathrm{CO}_{2}$ level or changes in ice sheet extent can be used for evaluation as well. Here we present implementations of the paleoclimate experiments proposed by the Coupled Model Intercomparison Project phase 5/Paleoclimate Modelling Intercomparison Project phase 3 (CMIP5/PMIP3) using MIROC-ESM, an ESM based on the global climate model MIROC (Model for Interdisciplinary Research on Climate). In this paper, experimental settings and spin-up procedures of the mid-Holocene, the Last Glacial Maximum, and the Last Millennium experiments are explained. The first two experiments are time slice experiments and the last one is a transient experiment. The complexity of the model requires various steps to correctly configure the experiments. Several basic outputs are also shown.
\end{abstract}

\section{Introduction}

For better future climate projection, evaluating climate models using experiments over different time scales is gaining recognition. As an experimental design, paleoclimate simulations provide unique opportunities to test models. Recent periods that are climatologically quite different to present-day conditions are targeted for the Coupled Model Intercomparison Project phase 5 (CMIP5; Taylor et al., 2011)/Paleoclimate Modelling Intercomparison Project phase 3 (PMIP3). Here we describe three paleoclimate experiments using MIROC-ESM - an Earth system model (ESM) based on MIROC (Model for Interdisciplinary Research on Climate) - which are conducted in the CMIP5/PMIP3 framework and for the Intergovernmental Panel on Climate Change 5th Assessment Report (IPCC AR5).

In this paper, we consider ESMs as coupled climate models with biogeochemical components which are capable of treating the carbon cycle online together with other climate components: in other words, climate models which can predict the atmospheric $\mathrm{CO}_{2}$ concentration. Among such ESMs, the models of higher complexity, consisting of atmosphereocean general circulation models (AOGCMs) coupled with biogeochemical components, are now available for paleoclimate simulations. These models allow evaluation of more components compared to the previous AGCM work in PMIP phase 1, or AOGCM inter-comparison in PMIP phase 2. As 
the carbon dioxide plays a crucial role in controlling radiation, ESMs are being increasingly used in global climate change projection.

For IPCC AR5, three paleoclimate experiments were officially listed in the CMIP5/PMIP3 project (Taylor et al., 2009; Otto-Bliesner et al., 2009): mid-Holocene (6000 yr before present time slice, hereafter $6 \mathrm{ka}$ ), Last Glacial Maximum (21000 yr before present time slice, hereafter LGM), and Last Millennium (850-1850 AD transient, hereafter LM). We briefly review the scientific questions that draw the attention of the paleoclimate community.

The pronounced characteristics in the climate reconstructed for $6 \mathrm{ka}$ are the enhancement of African and Asian summer monsoons and the associated pronounced vegetation changes over the Sahara desert (Hoelzmann et al., 1998; Jolly et al., 1998; Peyron et al., 2006). The enhancement and northward shift of the summer African and Asian monsoons were reported in PMIP phase 1 (Joussaume et al., 1999) and PMIP phase 2 (Braconnot et al., 2007). These changes were consistent in sign with paleoclimate proxy records, mostly from pollen (Kohfeld and Harrison, 2000; Prentice et al., 2000; Yu et al., 2000; Harrison et al., 2001, 2003; Bigelow et al., 2003; Pickett et al., 2004; Bartlein et al., 2010), but most of the models failed to simulate sufficiently high Holocene precipitation to maintain a vegetated Sahara (e.g. Doherty et al., 2000; Chikira et al., 2006). Much modelling work has investigated the vegetation feedback effect on the African monsoon change in $6 \mathrm{ka}$, and most have described the presence of positive feedback between vegetation and precipitation (Ganopolski et al., 1998; Doherty et al., 2000; Levis et al., 2004). Several studies have investigated the role of the ocean on the summer monsoons using AOGCMs, and most suggested that there is further enhancement of the African monsoon when the ocean is coupled. As for the Asian monsoon, it is still enhanced compared to $0 \mathrm{ka}$, but the signal is weaker due to the ocean feedback (Liu et al., 2003; Zhao et al., 2005, 2007; Ohgaito and Abe-Ouchi, 2007, 2009; Zhao and Harrison, 2011). Dallmeyer et al. (2010) used an ESM to investigate the effect of the ocean and vegetation component on the total change of the Asian monsoon, and found that the ocean plays a major role in the enhancement of precipitation. This demonstrates that experiments with ESMs coupled with dynamic global vegetation models provide an opportunity to evaluate the comprehensive influence on Asian and African monsoon change resulting from dynamic vegetation and oceans.

The LGM is characterized by a very cold and dry climate. The Laurentide and Fennoscandian ice sheets cover North America and Northern Europe (e.g. Denton and Hughes, 1981), atmospheric greenhouse gas (GHG) levels are reduced, and dust transportation is enhanced (e.g. Barnola et al., 1987; Petit et al., 1981). Land vegetation responds as well: subtropical deserts expand and forests generally regress (Colinvaux et al., 1996, 2000; Marchant et al., 2009). At high latitudes, boreal forests migrate southward, and are replaced by tundra and grassland (Prentice et al., 2000; Tarasov et al., 2000; Ray and Adams, 2001; Harrison and Prentice, 2003). Due to these significant differences from today, various aspects of the climate can be investigated. For example, attempts to constrain climate sensitivity using LGM cooling (Annan et al., 2005; Schmittner et al., 2011; Hargreaves et al., 2012), and the mechanism of the recorded weakening of the Atlantic meridional overturning circulation (AMOC) and the associated cooling in the North Atlantic Ocean (Weber et al., 2007; Murakami et al., 2008), have been major subjects since PMIP2. As for the atmospheric circulation, the southward shift of the Intertropical Convergence Zone (ITCZ) and changes in the Southern Hemisphere westerlies (Rojas et al., 2009) have also been studied. Temperature changes have been discussed in comparison with archives of proxy records (Otto-Bliesner et al., 2009; MARGO project members, 2009; Bartlein et al., 2010). With respect to the carbon cycle, the glacial-interglacial atmospheric $\mathrm{CO}_{2}$ variations remain an open issue (Kohfeld and Ridgwell, 2009). LGM climate experiments using ESM with an interactive carbon cycle will contribute to the understanding of the mechanisms controlling $\mathrm{CO}_{2}$ variations.

The LM includes two key climatic epochs: the "Medieval Climate Anomaly" (MCA, ca. 1000-1200 AD) and the "Little Ice Age" (LIA, ca. 1500-1850 AD). Recent progress on proxy-based climate reconstruction has slowly revealed the spatial and temporal extent of those climatic epochs (e.g. Trouet et al., 2009; Mann et al., 2009), which allows better comparison between data and GCM simulations. Such comparison is useful in verifying the ability of a climate model, and assists the understanding of the mechanisms contributing to the climate variability. More specifically, the need to distinguish anthropogenic climate change from natural climate variability at centennial to millennial time scales is one of the key issues of climatology, addressing the social demand for climate research. Several very large volcanic eruptions occurred during this period, causing global cooling as a response to the radiation changes. Combined with the reconstructions, they serve as ideal test cases to investigate the response of climate models. Volcanic activity may also play a key role in reproducing LIA cooling, by decadally paced volcanic activity starting around the 13th century (Zhong et al., 2011). LM experiments with fully coupled ESMs allow discussion of the evolution of the carbon cycle interacting with the climate variation over the last $1200 \mathrm{yr}$.

LM simulations appearing in the IPCC AR4 (IPCC Fourth Assessment Report, 2007) were performed mostly using Earth system models of intermediate complexity (EMICs) (e.g. Gerber et al., 2003; Goosse, 2005). Following some work with coupled models without a carbon cycle (e.g. Gonzáles-Rouco et al., 2003; Ammann et al., 2007; Servonnat et al., 2010), a LM experiment using an ESM has been reported recently (Jungclaus et al., 2010). Our study uses a similar approach in evaluating the strength of natural variability using up-to-date forcing reconstructions. 
This paper presents the technical aspects of CMIP5/PMIP3 paleoclimate experiments using MIROCESM, including model settings, choice of boundary conditions, special treatment for model spin-up, and the initial data preparation. It is not our intention to present scientific results in detail here, as these will be discussed in subsequent papers. In our preliminary results, we show the seasonal changes for $6 \mathrm{ka}$, whereas annual means for $21 \mathrm{ka}$ are presented. The forcing difference for $6 \mathrm{ka}$ is principally the orbital configuration, which causes the change in seasonal pattern of the incoming shortwave radiation. As for $21 \mathrm{ka}$, the different equilibrium state is achieved responding to the continental-scale topography and global albedo change, which should be represented by the annual means.

The model and its general characteristics are described in Sect. 2, specific settings for each paleoclimate experiment are described in Sect. 3 together with preliminary results, and concluding remarks follow in Sect. 4.

\section{General characteristics of the model}

MIROC-ESM is an ESM developed at the Japan Agency for Marine-Earth Science and Technology in collaboration with the Center for Climate System Research (CCSR), University of Tokyo, and the National Institute for Environmental Studies based on the MIROC AOGCM (K-1 model developers, 2004; Nozawa et al., 2007). Based on MIROC3.2, which is the previous version of MIROC used for the CMIP3 experiments, two versions are now available as AOGCM: the bug-fixed version MIROC4 and the new generation model MIROC5. MIROC-ESM is another branch of the MIROC series based on MIROC4, in which ecosystem components are introduced as an ESM. MIROC-ESM consists of an atmospheric general circulation model (MIROC-AGCM 2010), including an online aerosol component (SPRINTARS 5.00), an ocean GCM with sea ice component (COCO 3.4), a land surface model (MATSIRO), and terrestrial and marine ecosystem components. These are interactively coupled in MIROC-ESM, as illustrated in Fig. 1. These atmosphere, ocean, and land surface components, as well as a river routine, are coupled by a flux coupler (K-1 Model Developers, 2004). As an ESM, MIROC-ESM has a newly introduced atmospheric chemistry component (CHASER 4.1) and carbon cycle components for the land and ocean ecosystems. The carbon cycle is calculated by a marine biogeochemical component coupled with COCO (CCSR Ocean COmponent model) and a terrestrial ecosystem component dealing with dynamic vegetation (SEIB-DGVM) coupled with MATSIRO. Watanabe et al. (2011) gives detailed descriptions of each component and the model's performance against observed 20th-century climate variations.

The atmosphere and land components have a spatial resolution of T42 (equivalent grid interval is approximately $2.8^{\circ}$

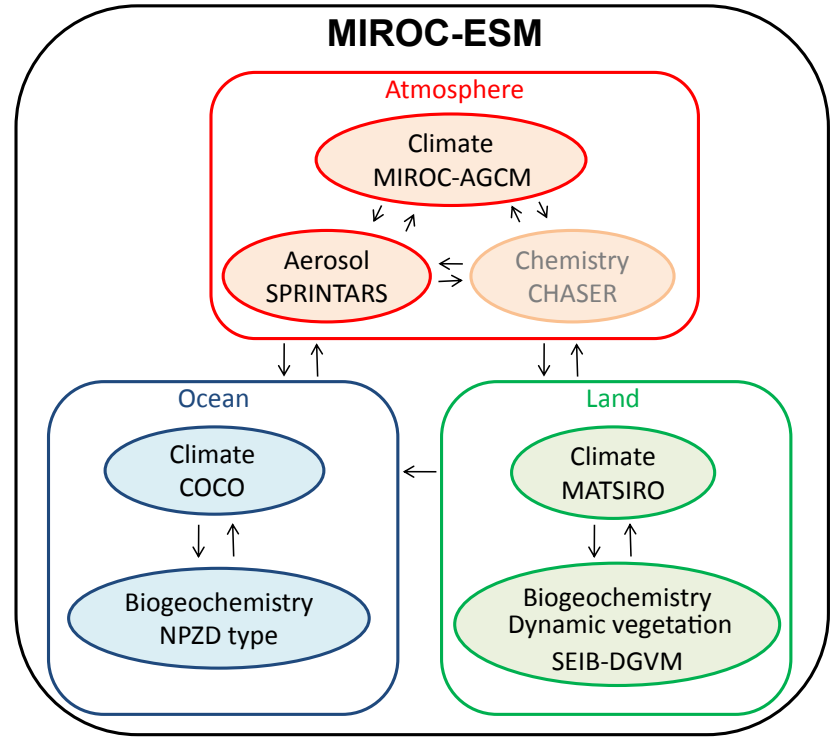

Fig. 1. The structure of MIROC-ESM. It consists of an atmospheric GCM (MIROC-AGCM) with an online aerosol component (SPRINTARS) and a chemistry component (CHASER), an ocean GCM with sea ice component (COCO), a land surface model (MATSIRO), and terrestrial and marine ecosystem components (SEIB-DGVM and NPZD-type model). Paleoclimate experiments described in this paper were performed without CHASER.

in latitude and longitude). The atmosphere has 80 vertical layers between the surface and the stratosphere up to about $0.003 \mathrm{hPa}$ (Watanabe et al., 2008). Due to the limited computational resources, part of the CMIP5 experiments were performed with the full version of MIROC-ESM, to which atmospheric chemistry component (CHASER) is coupled. Other experiments, including the paleoclimate experiments described in this paper, were performed without CHASER.

The ocean component $\mathrm{COCO}$ has a resolution of $1.4^{\circ}$ in longitude and $0.56-1.4^{\circ}$ in latitude in the horizontal and 44 levels in the vertical (K-1 Model Developers, 2004; Hasumi, 2000). No correction is applied in exchanging heat, water, and momentum flux between the atmosphere and the ocean. The sea ice model is based on a two-category thickness representation, has zero-layer thermodynamics (Semtner, 1976), and dynamics with elastic-viscous-plastic rheology (Hunke and Dukowicz, 1997).

The land surface component MATSIRO (Minimal Advanced Treatments of Surface Interaction and RunOff) consists of a single layer canopy, three layers of snow, and six layers of soil to a depth of $14 \mathrm{~m}$ (Takata et al., 2003). It has 11 types of land cover and soil (represented as land index; see Fig. 2), which classifies the ground surface conditions and provides the table of parameters for computing physical land processes. It is coupled to a river-routing model, TRIP (Total Runoff Integrating Pathways) (Oki and Sud, 1998), for calculating river discharge. The ageing effect on snow albedo 


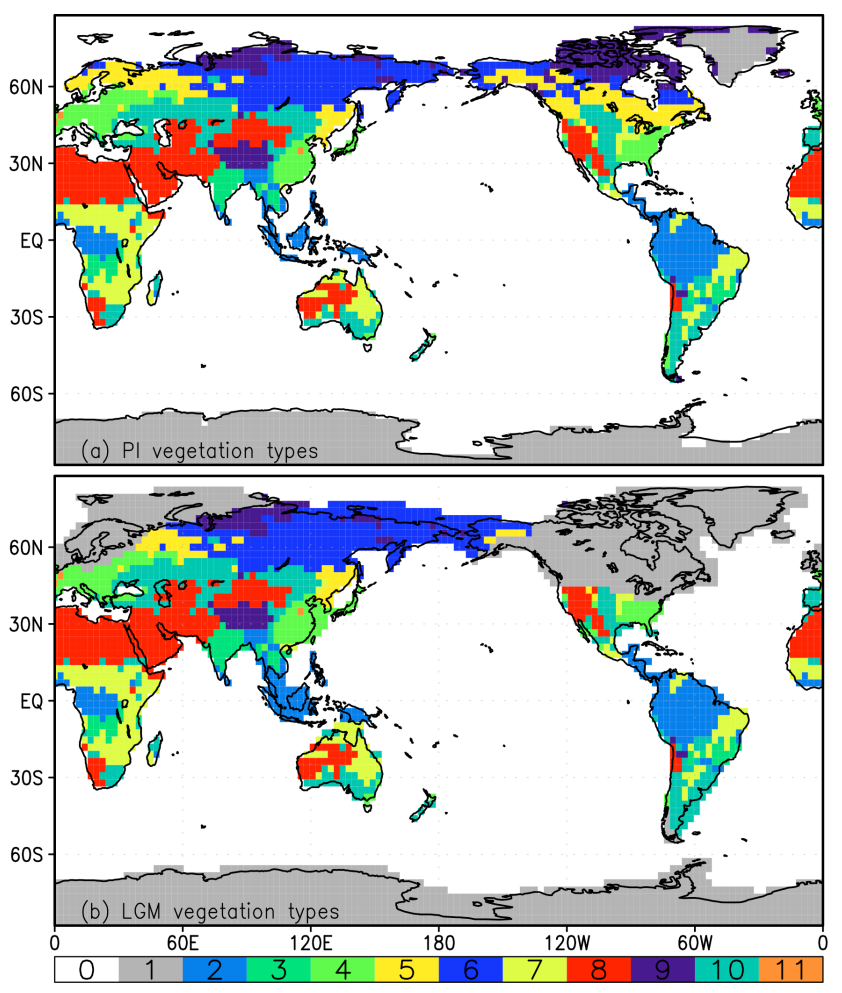

Fig. 2. The vegetation types for the land model MATSIRO for (a) PI and (b) LGM. \#0 - sea surface; \#1 - continental ice; \#2 - broadleaf evergreen forest; \#3 - broadleaf deciduous forest \& woodland; \#4 mixed coniferous \& broadleaf deciduous forest \& woodland; \#5 coniferous forest \& woodland; \#6 - high latitude deciduous forest \& woodland; \#7 - wooded C4 grassland; \#8 - shrubs \& bare ground; \#9 - tundra; \#10 - C3 grassland; \#11 - cultivation.

and the effects of dirt in snow have been taken into account (Yang et al., 1997; Aoki et al., 2006). The dirt concentration in snow is calculated from the deposition fluxes of dust and soot calculated in the aerosol module SPRINTARS (Spectral Radiation-Transport Model for Aerosol Species) (Takemura et al., 2000, 2002; Takemura, 2005).

MATSIRO is coupled with the terrestrial ecosystem model SEIB-DGVM (Spatially Explicit Individual-Based Dynamic Global Vegetation Model) (Sato et al., 2007; Ise et al., 2009). SEIB-DGVM adopts a scheme that explicitly captures light competition among trees, avoiding parameterized competition. Land vegetation is classified into 13 plant functional types (PFTs), and each PFT has different ecophysiological parameters and allometry relationships. This results in differential growth patterns and competition among PFTs under the environmental conditions in each grid cell. Leaf area index (LAI) is predicted at daily time steps by computing plant physiological processes, such as photosynthesis, respiration, growth, and mortality, based on the climatic conditions simulated by MIROC-ESM. The predicted LAI is then used for calculation of the biogeophysical processes in MAT-
SIRO: the processes for radiation transfer including surface albedo, interception of precipitation, and energy transfer by latent/sensible heat. In the current configuration, MATSIRO considers the dynamic variations in LAI, while the land index in MATSIRO is fixed, and neglects the PFT predicted by SEIB-DGVM. Thus, the terrestrial ecosystem in MIROCESM affects climate only through the carbon cycle and the LAI feedback.

The oceanic biogeochemical model is based on a simplified version of a nutrient-phytoplankton-zooplanktondetritus (NPZD) ecosystem model (Oschlies, 2001; Oschlies and Garçon, 1999). The oceanic biogeochemical tracers include nitrate, phytoplankton, zooplankton, detritus, calcium carbonate, calcium, alkalinity, and dissolved inorganic carbon (DIC). A constant Redfield ratio $(\mathrm{C} / \mathrm{N}=6.625)$ is used to estimate the carbon and calcium flow. The sea-air $\mathrm{CO}_{2}$ flux is calculated by multiplying the difference of oceanatmosphere $\mathrm{CO}_{2}$ partial pressures by the ocean gas solubility. These model components are all activated in our paleoclimate experiments which will be described in the next section.

\section{Experimental settings}

\subsection{Pre-industrial control experiment}

\subsubsection{Experimental setup}

The basic settings of the experiments are common with other simulations in CMIP5 by MIROC-ESM (Watanabe et al., 2011). Here, the pre-industrial control experiment (PI) is firstly described as a counterpart of the following paleoclimate simulations. PI is a time slice experiment forced by the climatic conditions at $1850 \mathrm{AD}$. The greenhouse gas levels (GHGs) are set to $285 \mathrm{ppm}$ for $\mathrm{CO}_{2}, 0.3 \mathrm{ppm}$ for $\mathrm{N}_{2} \mathrm{O}$ and $1.7 \mathrm{ppm}$ for $\mathrm{CH}_{4}$ (Table 1). The land index for MATSIRO is shown in Fig. 2a. A plausible distribution in 1850 is prepared based on modern vegetation types and historical land use data. The orbital parameters are set to 0.01672 for the eccentricity, $23.45^{\circ}$ for the obliquity, and $102.04^{\circ}$ for the angular precession. Although these orbital parameters have a considerable effect on longer time scales, they have had little impact on annual mean insolation on time scales shorter than the millennium. According to IPCC AR4, summer insolation decreased by $0.33 \mathrm{~W} \mathrm{~m}^{-2}$ at $45^{\circ} \mathrm{N}$ over the millennium, winter insolation increased by $0.83 \mathrm{~W} \mathrm{~m}^{-2}$ (Goosse, 2005), and the magnitude of the mean seasonal cycle of insolation in the Northern Hemisphere decreased by $0.4 \mathrm{~W} \mathrm{~m}^{-2}$.

\subsubsection{Initialization of the PI simulation}

Initial data for the PI experiment was prepared in stages. The procedure is presented in detail by Watanabe et al. (2011), the description paper of MIROC-ESM. Here we outline the procedure briefly in Fig. 3a. Starting with the "lowtop" version of MIROC-ESM with 20 vertical layers in the 
Table 1. The boundary conditions for each experiment.

\begin{tabular}{lllll}
\hline abbr. name & PI & 6 ka & LGM & LM \\
\hline period & pre-industrial & mid-Holocene & Last Glacial Maximum & Last Millennium \\
& 1850 AD & 6000 yr before present & 21000 yr before present & $850-1850$ AD \\
experiment no. in CMIP5 & exp. 3.1 & exp. 3.4 & exp. 3.5 & exp. 3.6 \\
type & time slice & time slice & time slice & transient \\
land boundary condition & pre-industrial & pre-industrial & LGM topography & pre-industrial \\
GHG: $\mathrm{CO}_{2}(\mathrm{ppm})$ & 285.0 & 280.0 & 185.0 & prognostic \\
GHG: $\mathrm{N}_{2} \mathrm{O}(\mathrm{ppm})$ & 0.31 & 0.27 & 0.20 & prescribed, variable in time \\
GHG: $\mathrm{CH}(\mathrm{ppm})$ & 1.7414 & 0.65 & 0.35 & prescribed, variable in time \\
orbit: eccentricity & 0.01672 & 0.018682 & 0.018994 & prescribed, variable in time \\
orbit: obliquity $\left.{ }^{\circ}\right)$ & 23.45 & 24.105 & 22.949 & prescribed, variable in time \\
orbit: angular precession $\left(^{\circ}\right)$ & 102.04 & 0.87 & 114.42 & prescribed, variable in time \\
\hline
\end{tabular}

atmosphere, a $380 \mathrm{yr}$ integration was performed. Spin-ups of land ecosystem (2000 yr) and ocean ecosystem (1245 yr) were separately performed beforehand and combined. A $50 \mathrm{yr}$ integration followed with an atmosphere with 80 vertical layers. In the course of the spin-up runs, representative states and fluxes in the physical climate (surface air temperatures, radiation fluxes at the top of the atmosphere, strength of the thermohaline circulation, sea ice extent) and carbon cycle components (soil and vegetation carbon storage) were monitored. The spin-up run was continued until linear trends in the last $50 \mathrm{yr}$ of these quantities became insignificant. Although the climatic trends were thought to be insignificant, a slight warming drift $\left(0.1^{\circ} \mathrm{C}\right.$ century ${ }^{-1}$ in global average surface air temperature) still existed in the PI experiment, which was overlooked during the spin-up procedure. It is considered to be due to the slow reduction in sea ice extent (of $3 \%$ century $^{-1}$ ) in the Southern Ocean, which caused a similar warming drift in the LM experiment (Sect. 3.4). Because of this drift, additional care is needed in analysis. After these spin-up procedures, a $630 \mathrm{yr}$ integration was carried out as the PI experiment. The last $100 \mathrm{yr}$ of the PI run are used as a reference for the analyses of the time slice experiments (6 ka and LGM). The trend is $+0.05^{\circ} \mathrm{C}$ in this period.

\subsubsection{Model performance}

In this section, the climate of the PI experiment is briefly presented comparing with the modern climate. Although the PI simulation is not necessarily comparable with modern-day observations, the aim of this section is to describe the characteristics of the PI climate, which is commonly used as a baseline to compare the paleoclimate experiments with proxy data. A detailed comparison of a present-day simulation with modern observations was already presented by Watanabe et al. (2011) using CMIP5 historical experiment. The PI mean value differs from the 20th-century ensemble mean analysed in Watanabe et al. (2011) by ca. $0.3{ }^{\circ} \mathrm{C}$ in global mean surface air temperature, but the spatial patterns of the bias are quite similar to each other. From this background, we discuss the difference between PI and observations in the following.

The sea surface temperature (SST) is shown in Fig. 4 in comparison with the World Ocean Atlas temperature data (WOA, 1998; Levitus et al., 1998). PI simulated reasonable SST distribution, though biases appear in the Pacific Convergence Zone, the Kuroshio region, and the eastern Equatorial Pacific. In the global average, slightly cooler SST in $\mathrm{PI}$ is reasonable considering the 20th-century warming. The distributions of simulated precipitation in comparison with observational data (Xie and Arkin, 1996) for boreal summer (JJAS) and winter (DJF) are shown in Fig. 5. The precipitation is underestimated along the South Pacific Convergence Zone (SPCZ) and over Central America, whereas it is overestimated over the Maritime Continent and the northwestern Indian Ocean. These shortcomings are similar to those in our previous model (MIROC3.2) because these two models have almost the same atmospheric physics components. For comparison with paleoclimate, reasonable representation of the ITCZ and precipitation distribution of the monsoon area is encouraging.

Further detailed comparison of observational data with the 20th-century part of the LM experiment would be beyond the scope of this paper, which aims at the description of the experimental settings.

\section{$3.2 \quad 6 \mathrm{ka}$}

\subsubsection{Forcing data and boundary conditions}

The 6 ka time slice experiment was performed following the PMIP3 protocol (Table 1). The boundary conditions are kept unchanged from the PI run except for the orbital parameters (eccentricity: 0.018682 ; angular precession: $0.87^{\circ}$; obliquity: $\left.24.105^{\circ}\right)$ and $\mathrm{GHG}$ concentrations $\left(\mathrm{CO}_{2}: 280.0 \mathrm{ppm} ; \mathrm{N}_{2} \mathrm{O}\right.$ : $\left.0.65 \mathrm{ppm} ; \mathrm{CH}_{4}: 0.27 \mathrm{ppm}\right)$. No volcanic activity was considered.

Since $6 \mathrm{ka}$ GHG levels are not drastically different from PI condition (except for methane), this experiment essentially 
(a) Preindustrial Control (PI)

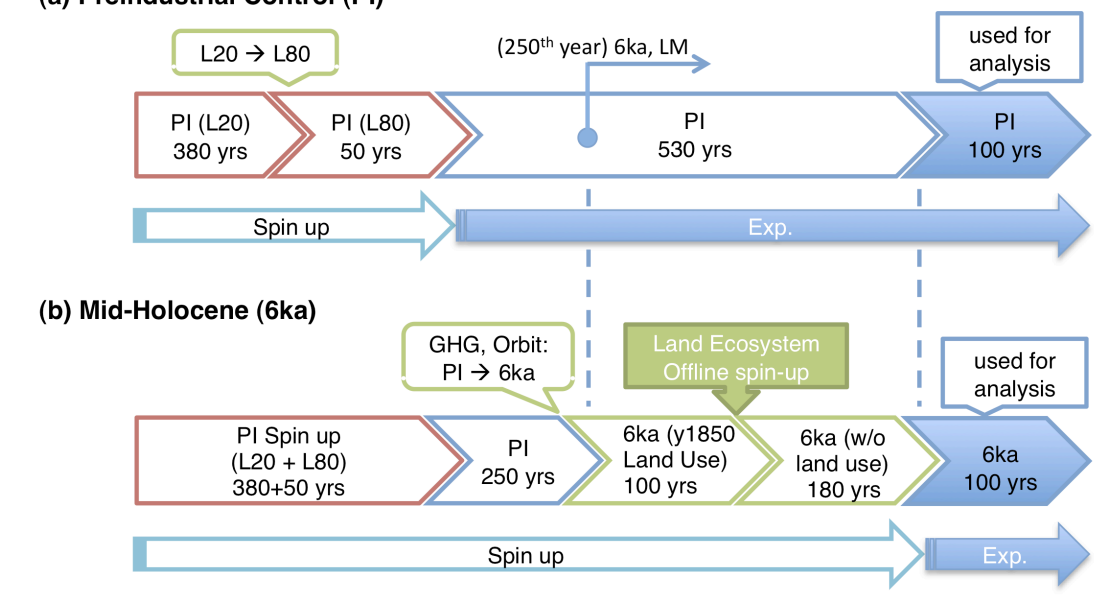

(c) Last Glacial Maximum (LGM: 21ka)

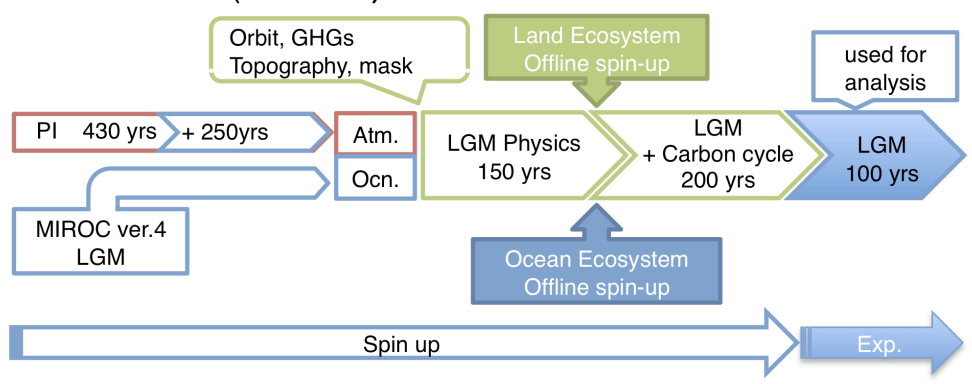

(d) Last Millennium (LM)

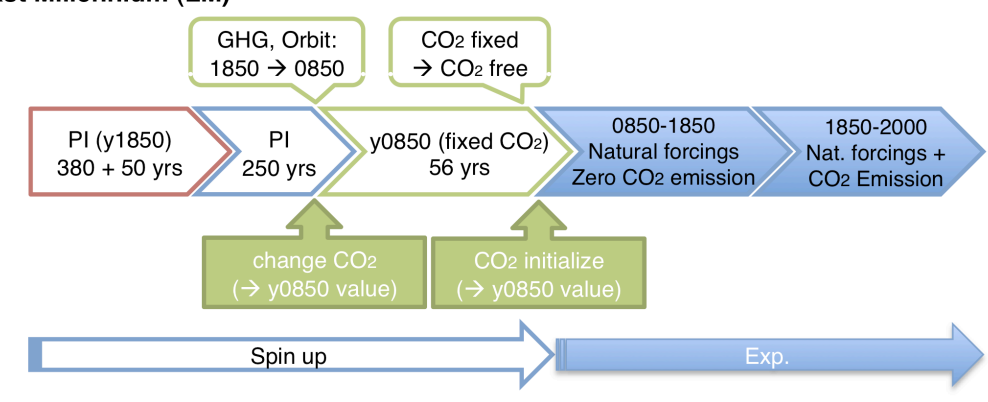

Fig. 3. The procedure of initial data preparation: (a) pre-industrial control: PI; (b) mid-Holocene: 6 ka; (c) Last Glacial Maximum (LGM): $21 \mathrm{ka}$; (d) Last Millennium: LM. Rounded rectangle denotes the change in boundary condition; shaded rectangle with arrow denotes the change in restart (initial) data, such as value overwriting and offline spin-up. For $6 \mathrm{ka}$, the integration time from the point of initialization (i.e. "branch" time) was kept the same as PI experiments (dashed blue line).

tests the climate response to a change in seasonal incoming shortwave radiation due to different orbital parameters (Fig. 6a). Incoming shortwave radiation is increased in boreal summer and decreased in austral summer. As for annual radiation, there is an increase in the high latitude, and a decrease in the tropics. Through these changes, seasonality is enhanced in the Northern Hemisphere and weakened in the Southern Hemisphere, especially at mid-latitudes.

\subsubsection{Preparation of the initial data}

Figure $3 \mathrm{~b}$ shows the procedure to set up the 6 ka experiment. It has been branched off year 250 of the PI run by replacing GHG levels and the orbital parameters with 6 ka values.

As the land surface condition in the PI experiment is based on the condition in year 1850 , some grid cells are classified as cropland. To perform the $6 \mathrm{ka}$ experiment, we need to replace such grid cells with the natural vegetation and to spin up the terrestrial ecosystem to a steady state without land use for cultivation. To shorten the spin-up time, the initialization 


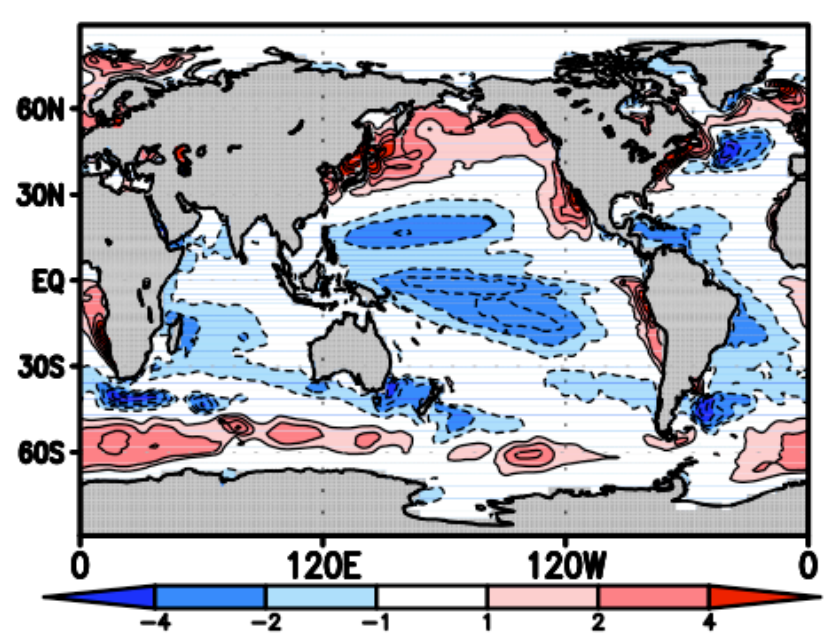

Fig. 4. The global annual mean sea surface temperature representation $\left({ }^{\circ} \mathrm{C}\right.$ ) of PI in comparison with World Ocean Atlas SST (WOA, 1998).

was conducted with the offline terrestrial ecosystem model that is used in MIROC-ESM. Firstly, $100 \mathrm{yr}$ of integration was performed with the $6 \mathrm{ka} \mathrm{GHG}$ concentrations and orbital forcing by MIROC-ESM. Using the last $25 \mathrm{yr}$ of this output, we ran the offline model for 2000 simulation years with the cycling $25 \mathrm{yr}$ climate forcing. This procedure is a similar approach to the one described in the protocol of the Coupled Climate Carbon Cycle Model Intercomparison Project (C4MIP, Fung et al., 2000; Cox et al., 2002). After this procedure, the quantities of terrestrial ecosystems were merged back into the restart data of MIROC-ESM, followed by a spin-up of 180 simulation years with all components coupled (Fig. 3b).

\subsubsection{Results}

The results of the $6 \mathrm{ka}$ experiment are also influenced by the warming drift identified in the PI experiment. In order to minimize the effect of drift, the following analyses are based on the anomalies between $6 \mathrm{ka}$ and PI, and the integration time from the point of initialization of $6 \mathrm{ka}$ (i.e. "branch" time) was kept the same for both experiments.

The changes in simulated temperature $6 \mathrm{ka}$ PI for JJAS and DJF are shown in Fig. 7. Pronounced changes are the warming over most of the boreal continents by $1-3{ }^{\circ} \mathrm{C}$ in JJAS in response to the strengthened solar radiation in the boreal summer. The tropical oceans are slightly cooled despite the increased incoming radiation, which is mainly due to the 23-month lags in ocean response (Braconnot et al., 2000). In DJF the cooling over the continents and the ocean are simulated as a response to the change in incoming radiation. The continents are cooled stronger by $1-4^{\circ} \mathrm{C}$, and the ocean is cooled by $0.5-1{ }^{\circ} \mathrm{C}$. The result is consistent with the PMIP2 multi-model ensemble (Braconnot et al., 2007).
The changes in simulated precipitation are shown in Fig. 8. In JJAS, increases of precipitation over the Sahel and northern India by $1-3 \mathrm{~mm} \mathrm{day}^{-1}$ and the reduction of precipitation south of these areas in similar magnitude are simulated. These precipitation changes and the circulation changes suggest an enhancement of the African and Asian monsoon. However, while these enhanced monsoons are consistent with the proxy records, the amount of precipitation over most of the Sahara Desert is not enough to explain the proxy records. In monitoring the daily predicted PFTs over the Sahara, SEIB-DGVM predicts non-desert vegetation more often than in the PI case, though non-desert PFTs are still much less frequent than desert vegetation. The monsoon activities for the boreal summer are investigated in another work (Ohgaito et al., 2012). In the Southern Hemisphere, a weakening of precipitation over the continents by $0-2 \mathrm{~mm}_{\text {day }}{ }^{-1}$ is simulated in DJF, which suggests the weakening of monsoon activities.

\subsection{LGM}

\subsubsection{Forcing data and boundary conditions}

The LGM experiment is an equilibrium experiment using the boundary conditions defined by the PMIP3 protocol (Table 1) except for the salinity setting. The PMIP3 protocol recommends increasing the mean ocean salinity by 1 PSU everywhere at the beginning of the simulation. In our experiment, however, the salinity setting was unchanged from the PI condition. A salinity-modified experiment remains to be done in the near future. The change in seawater density leads to change in the mixed layer, which may cause a change in airsea interaction. Atmospheric $\mathrm{CO}_{2} / \mathrm{N}_{2} \mathrm{O} / \mathrm{CH}_{4}$ concentrations, as well as orbital parameters, are set to the values shown in Table 1. The shortwave solar radiation deviation at the top of the atmosphere shown in Fig. $6 \mathrm{~b}$ is much smaller compared to the $6 \mathrm{ka}$ orbital change.

Another major difference in the LGM boundary condition is the topography. The Laurentide and Fennoscandian ice sheets covered wide areas of North America and the northern half of Europe. In the ESM, ice sheets are expressed as mountain ranges with albedo of ice (i.e. flow is not considered). Three ice sheet reconstructions are currently available: ICE-6G (Peltier, 2009; Argus and Peltier, 2009; Peltier and Drummond, 2008; Peltier et al., 2013), ANU Ice Model (Lambeck and Chappell, 2001; Lambeck et al., 2002, 2003), and GLAC-1 (Tarasov and Peltier, 2002, 2003). Since those reconstructions vary in topography, the settings of our experiment follow the "PMIP standard ice sheet" recommended by the PMIP3 committee, which averages the three reconstructions (PMIP3, 2010; Abe-Ouchi et al., 2013). The data provided by PMIP3 were regridded to T42 resolution and transformed to the spectral wave number space in order to adjust to the atmosphere and land component. The orographic difference for LGM-PI is shown in Fig. 9. 

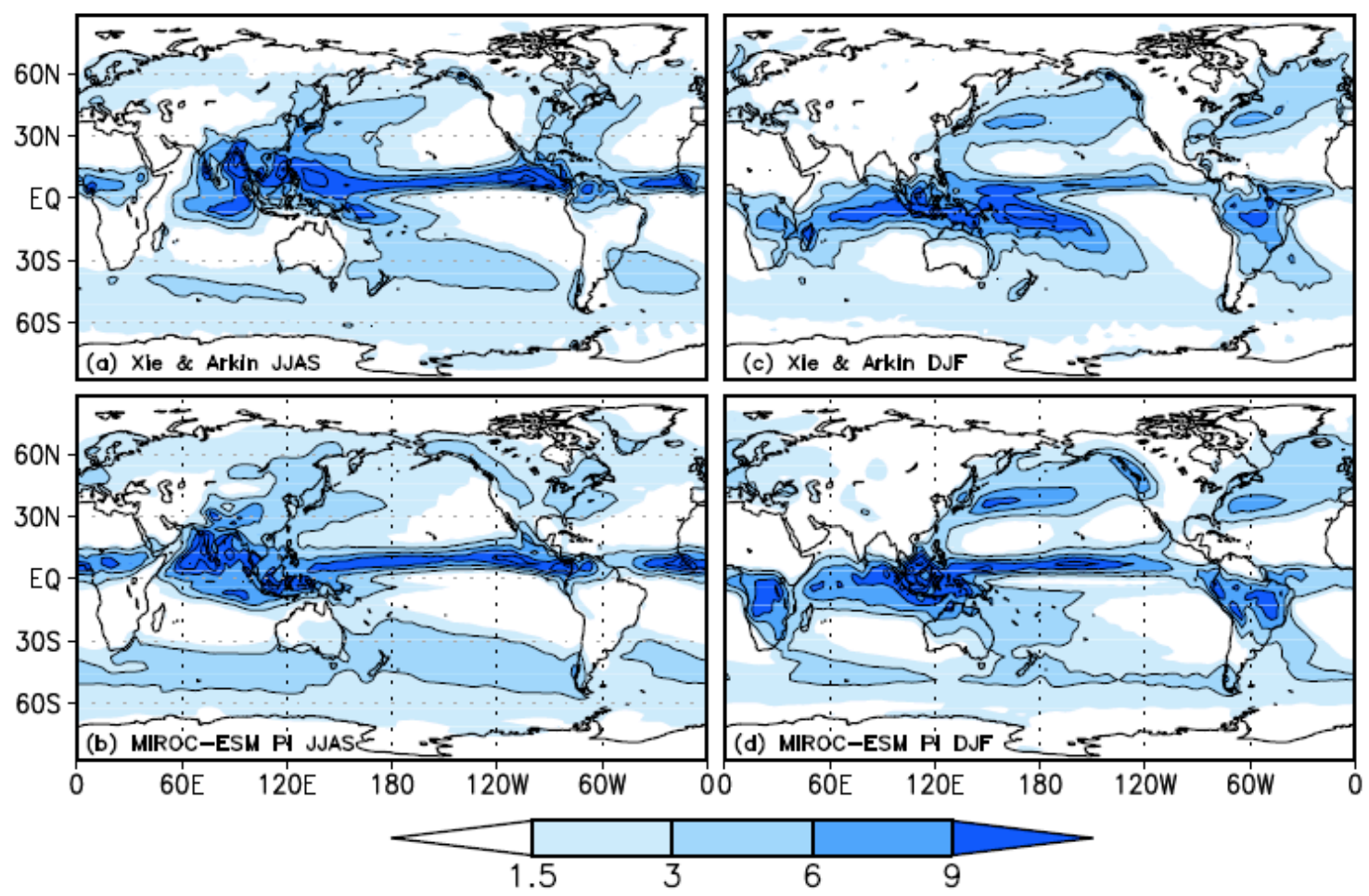

Fig. 5. The global precipitation distribution $\left(\mathrm{mm} \mathrm{day}^{-1}\right)$ of PI for JJAS and DJF (b, d) in comparison with re-analysis data (Xie and Arkin, 1996) (a, c).

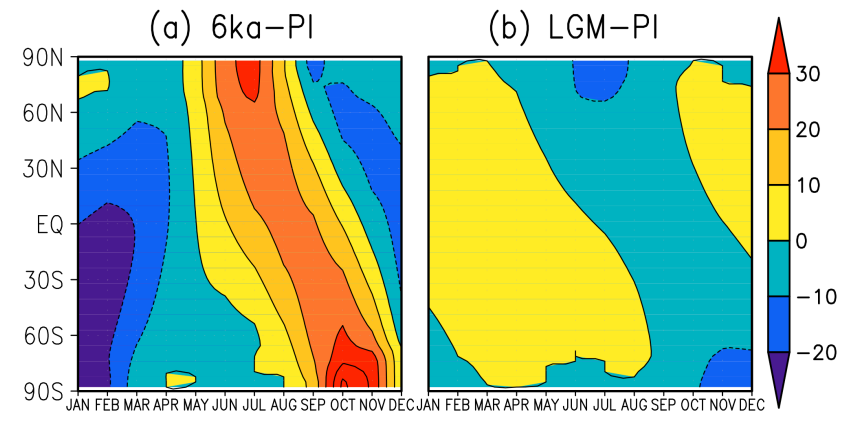

Fig. 6. The change in incoming shortwave radiation $\left(\mathrm{W} \mathrm{m}^{-2}\right)$ at the top of the atmosphere for (a) $6 \mathrm{ka}$ PI and (b) LGM-PI.

Sea level was lowered by about $90 \mathrm{~m}$, which closes the Bering Strait, and joins together the Indonesian maritime continent. Sea level change is set to $90 \mathrm{~mm}$ to maintain the consistency with the PMIP3 topography reconstruction (i.e. ice sheet topography). The total mass of the atmosphere was not adjusted. The vegetation boundary condition of the LGM simulation for MATSIRO was created based on the PI vegetation distribution. At first, the vegetation types in the ice sheet area given by the PMIP3 protocol are changed to ice sheet, and the rest of the land areas are basically not changed from PI. However, due to the lower sea level in the glacial climate, the area of the continental shelves should have some vegetation type specified, and the same vegetation types from neighbouring grid cells in zonal direction are given (Fig. 2b).

\subsubsection{Preparation of the initial data}

The initial data was prepared following the procedure shown in Fig. 3c. The initial condition of the ocean physical field is inherited from the result of the LGM experiment following the PMIP2 protocol with an earlier version of MIROC, MIROC4m (a bug-fixed version of MIROC3.2 (medres)), having the same resolution. This experiment has been integrated for $1900 \mathrm{yr}$ under PMIP2 LGM conditions and is regarded as being in equilibrium. Since the PMIP3 LGM ice sheet topography differs from the PMIP2 version, a spin-up for the ocean is necessary.

As the atmospheric initial condition, the PI experiment by MIROC-ESM is used, as is the case for the other two experiments. Since the atmosphere of MIROC-ESM has a different vertical coordinate system from previous versions, it is difficult to initialize the model by applying the initial condition of these old versions. Thus the atmospheric part taken from the 250th year of the PI run is combined with the above-mentioned ocean part. Then we conduct the spin-up for 150 model years using the coupled model, with the orbital parameters, GHG levels, topography, and the land-sea mask of LGM conditions. Since the adjustment time of the atmospheric physical field is considerably shorter than that of the 
(a) 6ka-PI JJAS

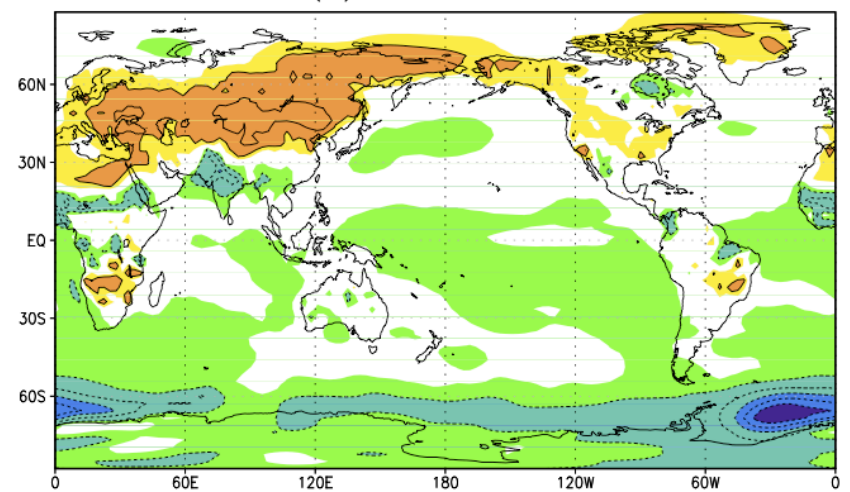

(b) $6 \mathrm{ka}-\mathrm{PI}$ DJF

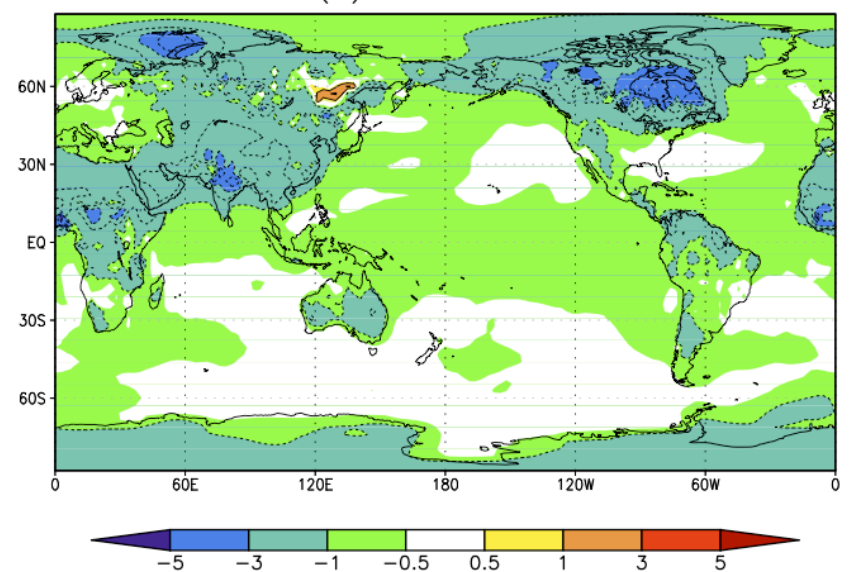

Fig. 7. The change in $2 \mathrm{~m}$ air temperature $6 \mathrm{ka}$ PI $\left({ }^{\circ} \mathrm{C}\right)$ for (a) JJAS and (b) DJF.

ocean, the atmospheric initial condition does not affect the length of the spin-up.

Meanwhile, special care is needed to start an integration under the new topography, which has the large ice sheets in the Northern Hemisphere. The surface pressure field must be adjusted to the change in surface elevation over the continents. As MIROC-ESM has high vertical resolution in the stratosphere, the model was sensitive to the topography change, generating gravity waves and breaking the CourantFriedrichs-Lewy condition by generating unrealistic high wind velocities. As recommended in the PMIP3 protocol, we changed the surface elevation gradually (in two stages, integrated one model year for adjustment), and also adjusted the initial pressure field to the LGM surface elevation when starting the integration under the new topography.

Since the atmospheric $\mathrm{CO}_{2}$ concentration in the LGM experiment needs to be reduced by ca. $100 \mathrm{ppm}$ compared to the PI condition, the carbon budget requires long integration to reach a steady state. After the physical field of ESM (i.e. atmosphere-ocean-land) achieved a quasi-equilibrium state, land and ocean biogeochemical components were run sepa- (a) $6 \mathrm{ka}-P I J J A S$

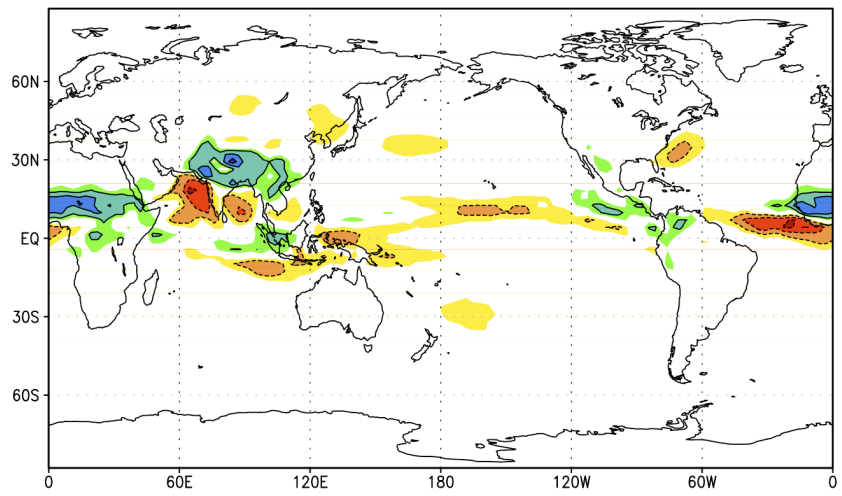

(b) $6 \mathrm{ka}-\mathrm{PI}$ DJF

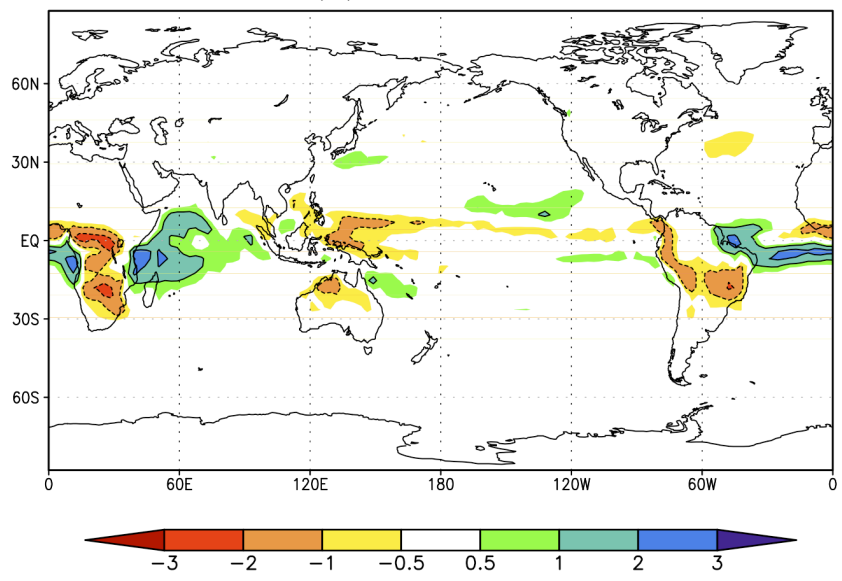

Fig. 8. The change in precipitation $6 \mathrm{ka} \mathrm{PI}\left(\mathrm{mm} \mathrm{day}^{-1}\right)$ for (a) JJAS and (b) DJF.

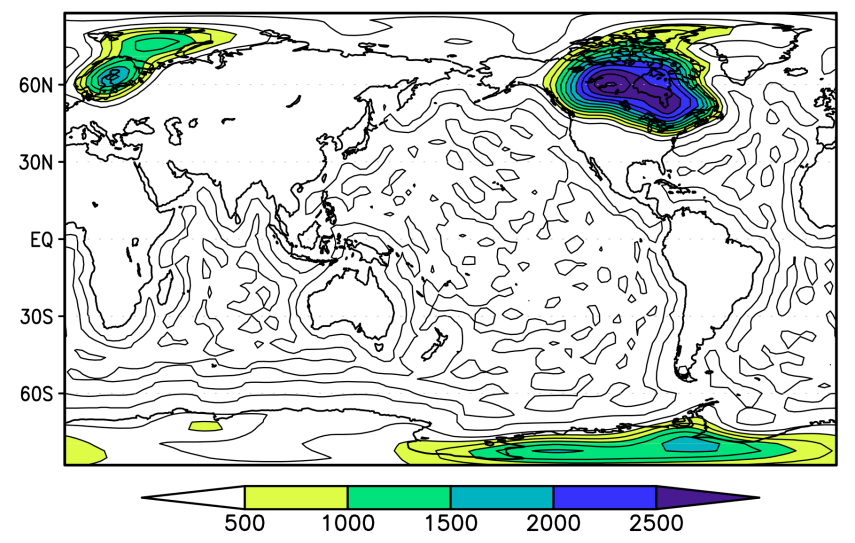

Fig. 9. The orography change for LGM-PI (m).

rately in an offline experiment, using the ESM outputs as the required inputs.

The variables of the terrestrial ecosystem were spun up using the offline land ecosystem model, as used in the $6 \mathrm{ka}$ experiment. The terrestrial variables were calculated for 2000 model years with the cyclic $25 \mathrm{yr}$ forcing of the LGM 


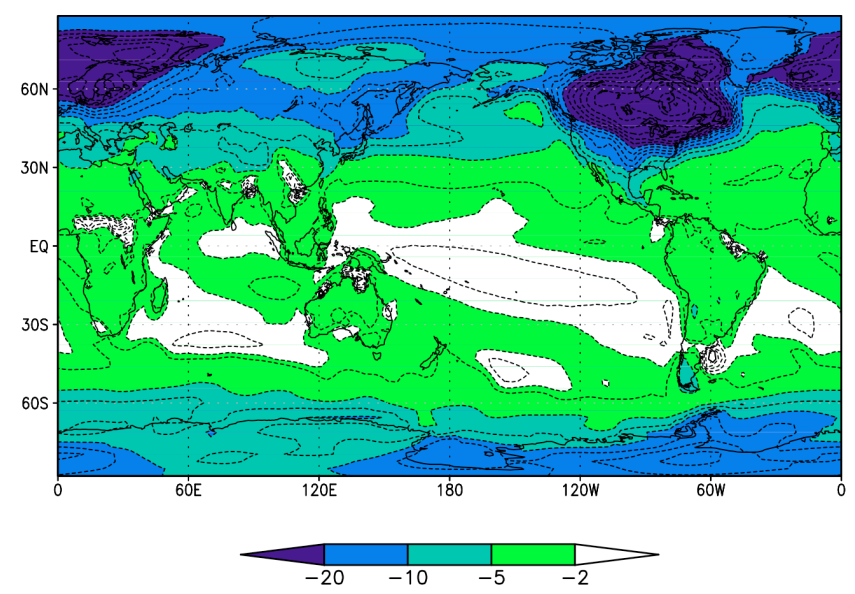

Fig. 10. The change in annual mean $2 \mathrm{~m}$ air temperature LGM-PI $\left({ }^{\circ} \mathrm{C}\right)$. Note the irregular contour intervals.

climate to obtain a steady state. During this process, the land use (cropland) is also reset to the potential natural vegetation. Distribution of the ice sheets was taken into account for suppressing the new vegetation and accumulation of soil carbon over the ice grid cells.

The spin-up of the oceanic ecosystem was performed in a similar manner. Starting from the PI condition, the offline model (Chikamoto et al., 2012) was integrated for 3500 model years with the LGM climatology (i.e. not cyclic forcing). The partial pressure of the atmospheric $\mathrm{CO}_{2}$ was set to $185 \mathrm{ppm}$, to calculate air-sea $\mathrm{CO}_{2}$ gas exchange. This setting forces the near-surface oceanic $p \mathrm{CO}_{2}$ to be $189 \mathrm{ppm}$ and achieved a new equilibrium of marine carbon distribution. It results in the removal of the oceanic $\mathrm{CO}_{2}$, which is equivalent to an increase of ca. $550 \mathrm{ppm} \mathrm{CO}_{2}$ in the atmosphere.

After these offline experiments had achieved equilibrium, variables were merged back into the experiment using MIROC-ESM, and the model was integrated over $200 \mathrm{yr}$ to obtain an equilibrium state for the whole system under the LGM condition. The final 100 model years are used for analysis.

\subsubsection{Results}

The change in simulated mean annual temperature for LGMPI is shown in Fig. 10. More than $20^{\circ} \mathrm{C}$ cooling over the Laurentide and Fennoscandian ice sheets is seen. The rest of the globe cooled much less. Tropical cooling ranges between 1 and $3{ }^{\circ} \mathrm{C}$, which is consistent with the proxy records (MARGO Project Members, 2009). Comparing the temperature response over land to the ocean, the continents cooled more than the ocean as in earlier work (e.g. Braconnot et al., 2007, 2012; Laîné et al., 2009). This relationship quantitatively agrees with other climate model outputs and proxy reconstructions (Schmidt et al., 2012).

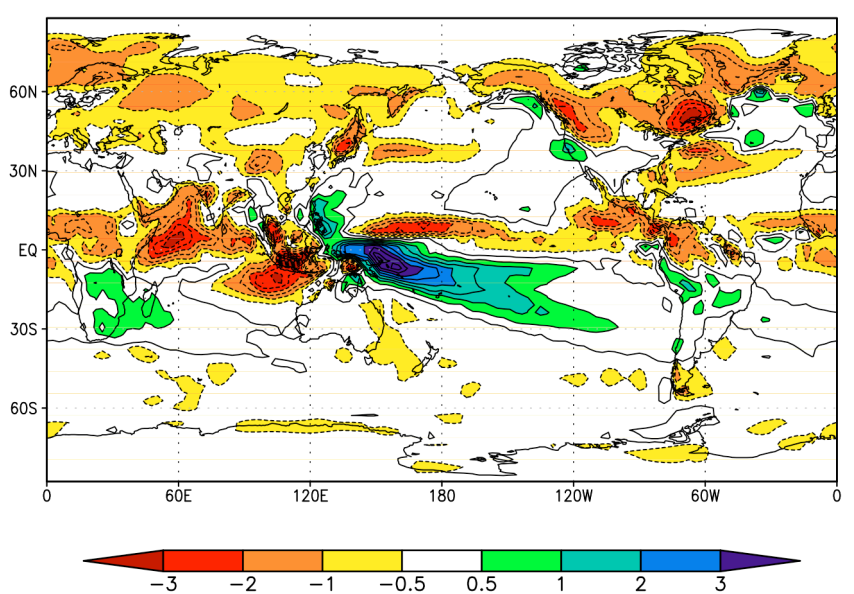

Fig. 11. The change in annual mean precipitation LGM-PI $\left(\mathrm{mm} \mathrm{day}^{-1}\right)$.

The changes in simulated annual precipitation are presented in Fig. 11. The precipitation was reduced for most of the simulated area, suggesting that a drier climate is associated with the cooling. The exception is the increased precipitation along the SPCZ, which is consistent with earlier work (e.g. Toracinta et al., 2004; Yin and Battisti, 2001). Toracinta et al. (2004) suggested that the difference in surface temperature gradients plays a major role in enhancing the SPCZ during LGM.

Although some proxy records suggest the weakening of the AMOC in LGM (McManus et al., 2004), the LGM experiment simulated ca. $32 \mathrm{~Sv}$, which is about $15 \mathrm{~Sv}$ stronger than that of PI (AMOC was defined by the maximum value of the stream function of the Atlantic meridional circulation at $\left.30^{\circ} \mathrm{N}\right)$. LGM AMOC shows the stronger variation in amplitude $( \pm 3-5 \mathrm{~Sv})$, with longer periods (5-8 yr), while PI AMOC shows weaker variation $( \pm 1-2 \mathrm{~Sv}, 3-4 \mathrm{yr})$. About half of the modelling studies have had a problem representing the weaker AMOC as suggested by the proxies (Weber et al., 2007). Oka et al. (2012) suggested that slight differences in surface cooling or wind stress forcing could lead to the different response of the AMOC. Further investigations are required to understand its behaviour.

The response of the carbon cycle and predicted vegetation in SEIB-DGVM are investigated in another work.

\subsection{LM}

The LM experiment is a transient experiment using timedependent boundary data, unlike the other experiments described in this paper. In addition, the experiment was carried out as a " $\mathrm{CO}_{2}$ prognostic" run, so that the atmospheric $\mathrm{CO}_{2}$ concentration was calculated by the model itself. It requires the additional procedure in preparing the data for atmospheric $\mathrm{CO}_{2}$ concentration. In this section, the preparation/selection of these data is described. 


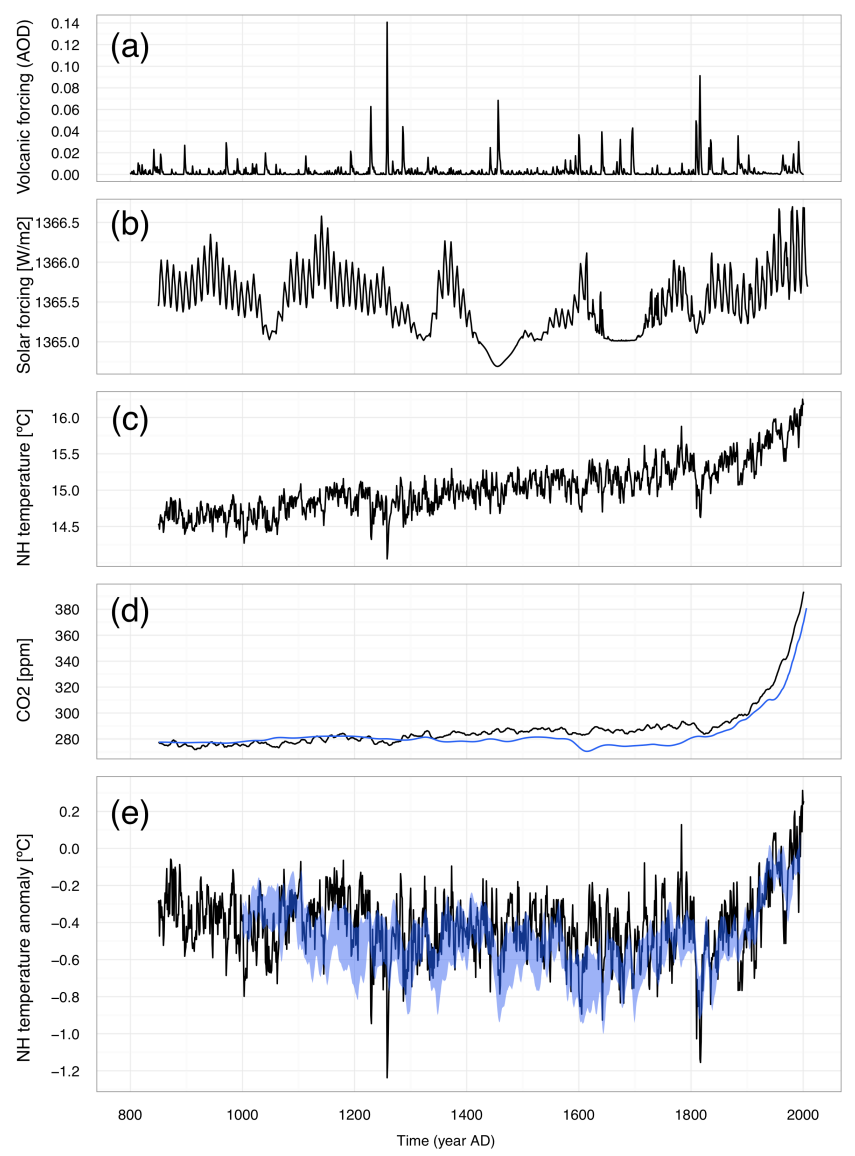

Fig. 12. The (a) volcanic and (b) solar forcing, (c) annual mean surface air temperature in the Northern Hemisphere, (d) modelpredicted (black) and reconstructed (blue) atmospheric $\mathrm{CO}_{2}$ concentration, and (e) detrended time series of mean annual surface air temperature anomaly (anomaly from the 1971-2000 mean). The blue shading represents the range of temperature reconstruction between the 20th and 80th percentile by Frank et al. (2010).

\subsubsection{Forcing data and boundary conditions}

The forcing data and boundary conditions for the LM experiment include (a) orbital forcing, (b) solar forcing, (c) volcanic forcing, (d) non- $\mathrm{CO}_{2}$ GHGs, and (e) cultivated land area (land use). In Fig. 12, the time series of volcanic and solar forcing data are shown (panel a and b).

Orbital forcing is based on a provided table of parameters (Berger, 1978), and the value is updated every year on 1 January. It affects the seasonality of incoming shortwave radiation, while total intensity is given by solar forcing data. As for solar forcing, multiple reconstructions of annual total solar irradiance (TSI) are available, and five reconstructions with different coverage periods are recommended in the PMIP3 protocol (Schmidt et al., 2012). Amongst these, we used Wang et al. (2005) (hereafter, WLS) for 1610-2000 AD and Delaygue and Bard (2010) (hereafter, DB) for 8501609 AD (Fig. 12b). WLS is based on a spectral reconstruc- tion and on a flux transport model using the observed sunspot record, while DB is based on an Antarctica stack of $10 \mathrm{Be}$ records. To splice WLS to DB, the amplitude of DB is scaled to the modern-to-Maunder Minimum TSI in the WLS reconstructions. The amplitude of high-frequency components (i.e. ca.11 yr period variation) is dependent on the solar activity. This resulted in very small amplitudes of high-frequency components during the 15th and 17th centuries. The radiation scheme in MIROC-ESM considers 29 spectral bands, in which spectrally resolved data provided by WLS can be used directly. The TSI data provided by DB are distributed consistently so that the spectrally integrated TSI agrees with the reconstruction. No enhanced variations in the UV region proposed by Lean et al. (2000) and used by Shindell et al. (2001) were applied. The parameterization for solar-derived ozone variations suggested by the PMIP3 protocol was not used either, to maintain the consistency with the already-conducted 20th-century experiments.

Two reconstructions of the volcanic forcing, Gao et al. (2008) and Crowley et al. (2008) as well as Crowley and Unterman (2012), are provided by the PMIP3 protocol, as time series of aerosol optical depth (AOD) variation. Both datasets are based on polar ice cores, but differ in their selection of ice cores, and the Gao data show stronger forcing in general. AOD estimates are based on a correlation between sulphate in the Antarctic ice cores and satellite AOD data, which were calibrated with the 1991 eruptions of Mt Pinatubo and Cerro Hudson (Sato et al., 1993). Aerosol size estimation is based on Pinto et al. (1989). In our experiment, Crowley data were used (Fig. 12a). The volcanic forcing is calculated using the AOD at $0.55 \mu \mathrm{m}$ and the effective radius calculated in MIROC-ESM for scaling. The data are provided at four latitude bands of equal area. After the year 1850, Sato et al. (1993, updated) is used for AOD data.

$\mathrm{CO}_{2}, \mathrm{CH}_{4}$ and $\mathrm{N}_{2} \mathrm{O}$ are considered as GHG forcing in the PMIP3 protocol, and a data table is provided (Joos, 2007; Schmidt et al., 2011). These data are derived from high-resolution ice cores in Antarctica (Battle et al., 1996; Etheridge et al., 1996, 1998; Ferretti et al., 2005; MacFarling Meure et al., 2006; Flückiger et al., 1999, 2002; Machida et al., 1995), connected to the instrumental data (Hansen and Sato, 2004) using a spline fit, with some adjustment (Joos and Spahni, 2008). For the atmospheric $\mathrm{CO}_{2}$ concentration, however, we decided to perform $\mathrm{LM}$ as a prognostic $\mathrm{CO}_{2} \mathrm{ex}-$ periment in which $\mathrm{CO}_{2}$ is calculated online (i.e. $\mathrm{CO}_{2}$ concentration predicted by the carbon cycle component is used for radiation transfer calculation), aiming to discuss the response of carbon cycle to the solar and volcanic forcings during LM. Since the majority of CMIP5/PMIP3 LM runs are " $\mathrm{CO}_{2}$ given", this was an unusual approach among CMIP5/PMIP3 experiments. The model predicts $\mathrm{CO}_{2}$ using emission data. Anthropogenic emissions are considered only after $1850 \mathrm{AD}$, while emissions are assumed to be zero for the 850-1850 AD period. $\mathrm{CH}_{4}$ and $\mathrm{N}_{2} \mathrm{O}$ are given as per the PMIP3 data table. 
As a difference from the PMIP3 protocol, the cultivated land area was assumed to be unchanged. The land use for the 1850 condition was applied throughout the experiment including the spin-up period.

\subsubsection{Preparation of initial data}

As is the case with the $6 \mathrm{ka}$ experiment, pre-industrial physical fields (i.e. from PI experiment) of the atmosphere and ocean were used for the initial condition of LM spin-up. Since the forcing conditions (orbital parameters, solar irradiance and GHG concentrations) are quite similar between the pre-industrial period and years around $850 \mathrm{AD}$, PI can be regarded as an initial condition for the $850 \mathrm{AD}$ simulation.

Figure $3 \mathrm{~d}$ shows the procedure of the spin-up. The 250th year of the PI experiment was used as the initial state, then $56 \mathrm{yr}$ of integration were completed under the year-850 condition, with fixed GHG (including $\mathrm{CO}_{2}$ ) concentration. Then $\mathrm{CO}_{2}$ concentration was set to be free, so that the modelcalculated value is used in the radiation process of the atmosphere component. The initial value of the $\mathrm{CO}_{2}$ concentration for the " $\mathrm{CO}_{2}$ free" experiment was reset from $298.71 \mathrm{ppm}$ to the level of $279.3 \mathrm{ppm}$ (i.e. value at year 850; Joos, 2007), as the transient simulation was started. This resetting procedure was performed to maintain consistency with the reconstructed value, and also to avoid unnecessary $\mathrm{CO}_{2}$ feedback. We adopted this procedure from the protocol of C4MIP (Fung et al., 2000; Cox et al., 2002). It breaks the conservation of the total carbon in a precise sense, but the effect is small enough to be neglected in evaluating the total budget.

\subsubsection{Results and time series}

Figure 12 shows the time series of forcing data and the simulated results. The volcanic and the solar forcings are shown in Fig. 12a and b, respectively, and the simulated annual mean surface air temperature in the Northern Hemisphere is shown in Fig. 12c. The warming drift in temperature is visible during the period until the 19th century (ca. $9 \times 10^{-2}{ }^{\circ} \mathrm{C} 100 \mathrm{yr}^{-1}$ ), while the warming during the 20th century is more pronounced (ca. $0.5^{\circ} \mathrm{C} 100 \mathrm{yr}^{-1}$ ). The drift is also visible in the PI experiment, which is caused by a decreasing trend in the Southern Ocean sea ice. It is likely due to an insufficiency of the initialization. Removing the trend is necessary to discuss the long-term climate variations.

Figure $12 \mathrm{e}$ shows the same temperature time series as Fig. 12c but with the linear trend of warming drift observed in the PI experiment subtracted $\left(0.094^{\circ} \mathrm{C} 100 \mathrm{yr}^{-1}\right)$. The air temperature represents anomalies $\left({ }^{\circ} \mathrm{C}\right)$ from the 1971-to2000 mean, and is averaged over the Northern Hemisphere for the comparison with proxy records. The slope of the trend was calculated from linear regression of the PI experiment results for the period between the year 250 and year 630 (i.e. after the "branching"). The blue shade in Fig. 12e represents the range of temperature reconstruction between the 20th and 80th percentile by Frank et al. (2010).

Considering that the proxy data cannot reflect the highfrequency variations, the time series of the simulated temperature roughly follows the reconstructions for most of the period (Fig. 12e). However, contrary to the good agreement after the year 1700, some discrepancies can be seen in the earlier periods. For example, the simulated values do not show a clear indication of the LIA, while the reconstruction shows relatively low temperature in the 16 th to 17 th centuries. The mismatch is also large during the 12th century, where the simulated temperature tends to be higher than the reconstruction. The model also seems to overestimate the responses to the very large volcanic events (e.g. year 1229, 1258, 1809, 1816), but this could be due to the limitation of detection capability of the reconstruction method (Mann et al., 2012).

Comparing the simulated temperature anomaly with the forcing data (panel a and b in Fig. 12), it is clear that volcanic aerosols have a strong influence on the surface air temperature, while the solar irradiance has minor effects. Under the current set-up of the model, LM climate variations should depend mainly on those two types of forcing. The faint LIA is considered to be due to the relatively constant solar forcing.

The simulated atmospheric $\mathrm{CO}_{2}$ concentration (Fig. 12d, black line, shown with the reconstructed value in blue) is stable in the model over the pre-industrial period, while it shows a sharp increase after 1850 , the period during which anthropogenic emissions are considered. It shows about $400 \mathrm{ppm}$ near the surface in the year 2001, while the observed value in Mauna Loa was 370.13 ppm (Tans and Keeling, 2011) in the same year. Considering that the simulated value at year 1850 was $289.5 \mathrm{ppm}$, which is ca. $5 \mathrm{ppm}$ higher than the reconstruction, the model still shows a tendency of slight overestimation. This is partly attributable to the warming drift of the global temperature.

\section{Conclusions and outlook}

The three paleoclimate experiments, $6 \mathrm{ka}$, LGM, and LM, proposed in CMIP5/PMIP3 were performed using MIROCESM. Overall, MIROC-ESM gave qualitatively reasonable results for all three cases. Special care was required when conducting experiments with conditions significantly different from modern simulations, especially using a highly complex model like ESM.

The 6 ka experiment was relatively simple, requiring spinup only for the land carbon cycle. The results showed reasonable seasonal changes in the temperature distribution in response to the insolation change. The precipitation and the circulation changes suggest the enhancement of the summer African and Asian monsoons. These changes are consistent in sign with the paleoenvironmental proxy records, but the enhancement over the Sahara Desert was not large enough, 
as also seen in previous modelling studies (e.g. Joussaume et al., 1999; Braconnot et al., 2007).

The LGM experiment required several steps before starting the simulation. Large change in topography requires a careful adjustment to avoid the numerical instabilities by gravity waves, and very long integration for spin-up is required for the ocean physical state and carbon cycle variables. In this experiment, ocean values are taken from a LGM experiment using the previous version of MIROC AOGCM, and the spin-up for the carbon cycle was performed separately. In the results, changes in temperature and precipitation are mostly consistent with the SSTs and the pollen proxy records (MARGO Project Members, 2009; Bartlein et al., 2010). AMOC was stronger, which is contrary to the results from some reconstructions. This discrepancy is an issue for some climate models (Otto-Bliesner et al., 2007), which should be discussed in another study.

In the LM experiment, the same settings as the PI experiment were used for the fixed boundary conditions. As it is a transient experiment, preparations for time-dependent forcing data are required. Since the experiment was performed as " $\mathrm{CO}_{2}$ prognostic", the time series of carbon emission data and initialization of the atmospheric $\mathrm{CO}_{2}$ are also required. After the removal of the linear-regressed temperature trend, the result shows general agreement with the reconstructed hemispheric temperature variations. Since this experiment depends on solar and volcanic forcing data, updating and cross checking of the data, both for the forcing and proxy records, are continuously required.

It is again recognized that a careful and sufficiently long spin-up is mandatory to achieve an equilibrium state, especially for such a long transient simulation as LM. In ESMs, more processes in land and ocean biogeochemistry are considered, and typical timescales are different among them. In addition to the physical model part, an initialization of the carbon cycle part is also necessary.

In this paper, we have documented the implementation of the CMIP5/PMIP3 experimental protocol for paleoclimate simulations using MIROC-ESM, with some overview of the results. We have successfully performed the experiments as described here, and the results are available via the CMIP5 database (Taylor et al., 2012). Further analysis of each setting, as well as multi-model ensemble analysis, will follow this paper to contribute to the CMIP5 modelling activity.

Acknowledgements. The authors are deeply grateful to the two anonymous referees for providing a thorough review and constructive comments. Our manuscript was improved significantly thanks to their support.

This study was supported by the Innovative Program of Climate Change Projection for the 21st century, MEXT, Japan. The numerical simulations in this study were performed using the Earth Simulator, and figures were drawn using GTOOL and GrADS, and R. NODC_WOA98 (World Ocean Atlas 1998) data were provided by the NOAA/OAR/ESRL PSD, Boulder, Colorado, USA, from their website at http://www.esrl.noaa.gov/psd/. This study is supported in part by the Funding Program for Next Generation World-Leading Researchers by the Cabinet Office, Government of Japan (GR079), by the Green Network of Excellence Arctic Climate Change Research Project, MEXT, Japan, and by the Global Environment Research Fund (S-10) of the Japanese Ministry of the Environment.

Edited by: R. Redler

\section{References}

Abe-Ouchi, A., Braconnot, P., Kageyama, M., Lambeck, K., Okuno, J., Otto-Bliesner, B. L., Peltier, W. R., Peterschmitt, J.-Y., Ritz, C., Saito F., Sueyoshi, T., and Tarasov, L.: Experimental Design and Ice sheet for PMIP3/CMIP5 LGM, in preparation, 2013.

Ammann, C. M., Joos, F., Schimel, D. S., Otto-Bliesner, B. L., and Tomas, R. A.: Solar influence on climate during the past millennium: Results from transient simulations with the NCAR Climate System Model, Proc. Natl. Aca. Sci. USA, 104, 3713-3718, 2007.

Annan, J. D., Hargreaves, J. C., Ohgaito, R., and Emori, S.: Efficiently Constraining Climate Sensitivity with Ensembles of Paleoclimate Simulations, Scientific Online Lett. Atmos., 1, 181184, doi:10.2151/sola.2005-047, 2005

Aoki, T., Motoyoshi, H., Kodama, Y., Yasunari, T. J., Sugiura, K., and Kobayashi, H.: Atmospheric Aerosol Deposition on Snow Surfaces and Its Effect on Albedo, October, Scientific Online Lett. Atmos., 2, 13-16, doi:10.2151/sola.2006-004, 2006.

Argus, D. F. and Peltier, W. R.: Constraining models of postglacial rebound using space geodesy: a detailed assessment of model ICE-5G (VM2) and its relatives, Geophys. J. Int., 181, 697-723, doi:10.1111/j.1365-246X.2010.04562.x, 2010.

Barnola, J. M., Raynaud, D., Korotkevich, Y. S., and Lorius, C.: Vostok ice core provides 160000-year record of atmospheric $\mathrm{CO}_{2}$, Nature, 329, 408-414, doi:10.1038/329408a0, 1987.

Bartlein, P. J., Harrison, S. P., Brewer, S., Connor, S., Davis, B. A. S., Gajewski, K., Guiot, J., Harrison-Prentice, T. I., Henderson, A., Peyron, O., Prentice, I. C., Scholze, M., Seppä, H., Shuman, B., Sugita, S., Thompson, R. S., Viau, A. E., Williams, J., and $\mathrm{Wu}, \mathrm{H} .:$ Pollen-based continental climate reconstructions at 6 and $21 \mathrm{ka}$ a global synthesis, Clim. Dynam., 37, 775-802, doi:10.1007/s00382-010-0904-1, 2010.

Battle, M., Bender, M., Sowers, T., Tans, P. P., Butler, J. H., Elkins, J. W., Ellis, J. T., Conway, T., Zhang, N., Lang, P., and Clarke, A. D.: Atmospheric gas concentrations over the past century measured in air from firn at the South Pole, Nature, 383, 231-235, 1996.

Berger, A. L.: Long-term variations of daily insolation and Quaternary climatic changes, J. Atmos. Sci., 35, 2362-2367, doi:10.1175/1520-0469(1978)035<2362:LTVODI > 2.0.CO;2, 1978.

Bigelow, N. H., Brubaker, L. B., Edwards, M. E., Harrison, S. P., Prentice, I. C., Anderson, P. M., Andreev, A. A., Bartlein, P. J., Christensen, T. R., Cramer, W., Kaplan, J. O., Lozhkin, A. V., Matveyeva, N. V., Murray, D. F., Mcguire, A. D., Razzhivin, V. Y., Ritchie, J. C., Smith, B., Walker, D. A., Gajewski, K., Wolf, V., Holmqvist, B. H., Igarashi, Y., Kremenetskii, K., Paus, A., Pisaric, M. F. J., and Volkova, V. S.: Climate change and Arctic 
ecosystems: 1. Vegetation changes north of 55 degrees $\mathrm{N}$ between the last glacial maximum, mid-Holocene, and present, J. Geophys. Res., 108, 8170, D19, 10.1029/2002JD002558, 2003.

Braconnot, P., Marti, O., Joussaume, S., and Leclainche, Y.: Ocean Feedback in Response to $6 \mathrm{kyr}$ BP Insolation, J. Climate, 13, 1537-1553, doi:10.1175/15200442(2000)013<1537:OFIRTK> 2.0.CO;2, 2000.

Braconnot, P., Otto-Bliesner, B., Harrison, S., Joussaume, S., Peterchmitt, J.-Y., Abe-Ouchi, A., Crucifix, M., Driesschaert, E., Fichefet, Th., Hewitt, C. D., Kageyama, M., Kitoh, A., Laîné, A., Loutre, M.-F., Marti, O., Merkel, U., Ramstein, G., Valdes, P., Weber, S. L., Yu, Y., and Zhao, Y.: Results of PMIP2 coupled simulations of the Mid-Holocene and Last Glacial Maximum Part 1: experiments and large-scale features, Clim. Past, 3, 261277, doi:10.5194/cp-3-261-2007, 2007.

Braconnot, P., Harrison, S. P., Kageyama, M., Bartlein, P. J., Masson-Delmotte, V., Abe-Ouchi, A., Otto-Bliesner, B., and Zhao, Y.: Evaluation of climate models using palaeoclimatic data, Nat. Climate Change, 2, 417-424, doi:10.1038/nclimate1456, 2012.

Chikamoto, M. O., Abe-Ouchi, A., Oka, A., Ohgaito, R., and Timmermann, A.: Quantifying the ocean's role in glacial $\mathrm{CO}_{2}$ reductions, Clim. Past, 8, 545-563, doi:10.5194/cp-8-545-2012, 2012.

Chikira, M., Abe-Ouchi, A., and Sumi, A.: General circulation model study on the green Sahara during the mid-Holocene: An impact of convection originating above boundary layer, J. Geophys. Res., 111, D21103, doi:10.1029/2005JD006398, 2006.

Colinvaux, P., DeOliveira, P., Moreno, J., Miller, M., and Bush, M.: A long pollen record from lowland Amazonia: Forest and cooling in glacial times, Science, 274, 85-88, 1996.

Colinvaux, P., De Oliveira, P., and Bush, M.: Amazonian and neotropical plant communities on glacial time-scales: The failure of the aridity and refuge hypotheses, Quaternary Sci. Rev., 19, 141-169, doi:10.1126/science.274.5284.85, 2000.

Cox, P. M., Friedlingsteinm P.m and Rayner, P.: Modelling climatecarbon cycle feedbacks: A cross disciplinary collaboration prioritym IGBP Global Change Newslet., 49, 12-14, 2002.

Crowley, T. J. and Unterman, M. B.: Technical details concerning development of a 1200-yr proxy index for global volcanism, Earth Syst. Sci. Data Discuss., 5, 1-28, doi:10.5194/essdd-5-12012, 2012.

Crowley, T., Zielinski, G., Vinther, B., Udisti, R., Kreutz, K., ColeDai, J., and Castellano, E.: Volcanism and the little ice age, PAGES news, 16, 22-23, 2008.

Dallmeyer, A., Claussen, M., and Otto, J.: Contribution of oceanic and vegetation feedbacks to Holocene climate change in monsoonal Asia, Clim. Past, 6, 195-218, doi:10.5194/cp-6-1952010, 2010.

Delaygue, G. and Bard, E.: An Antarctic view of Beryllium-10 and solar activity for the past millennium, Clim. Dynam., 36, 22012218, doi:10.1007/s00382-010-0795-1, 2010.

Denton, G. H. and Hughes, T. J.: The Last Great Ice Sheets, Wiley Interscience, New York, 484 pp. and map portfolio, 1981.

Doherty, R., Kutzbach, J., Foley, J., and Pollard, D.: Fully coupled climate/dynamical vegetation model simulations over Northern Africa during the mid-Holocene, Clim. Dynam., 16, 561-573, doi:10.1007/s003820000065, 2000.

Etheridge, D. M., Steele, L. P., Langenfelds, R. L., Francey, R. J., Barnola, J. M., and Morgan, V. I.: Natural and anthropogenic changes in atmospheric $\mathrm{CO}_{2}$ over the last 1000 years from air in Antarctic ice and firn, J. Geophys. Res., 101, 4115-4128, doi:10.1029/95JD03410, 1996.

Etheridge, D. M., Steele, L. P., Francey, R. J., and Langenfelds, R. L.: Atmospheric methane between 1000 A.D. and present: Evidence of anthropogenic emissions and climatic variability, J. Geophys. Res., 103, 15979-15993, doi:10.1029/98JD00923, 1998.

Ferretti, D. F., Miller, J. B., White, J. W. C., Etheridge, D. M., Lassey, K. R., Lowe, D. C., Macfarling Meure, C. M., Dreier, M. F., Trudinger, C. M., Van Ommen, T. D., and Langenfelds, R. L.: Unexpected changes to the global methane budget over the past 2000 years, Science, 309, 1714-1717, 2005.

Flückiger, J., Dallenbach, A., Blunier, T., Stauffer, B., Stocker, T., Raynaud, D., and Barnola, J.: Variations in atmospheric $\mathrm{N}_{2} \mathrm{O}$ concentration during abrupt climatic changes, Science, 285, 227 30, 1999.

Flückiger, J., Monnin, E., Stauffer, B., Schwander, J., Stocker, T. F., Chappellaz, J., Raynaud, D., and Barnola, J. M.: High resolution Holocene N2O ice core record and its relationship with CH4 and CO2, Global Biogeochem. Cy., 16(1), 1010, doi:10.1029/2001GB001417, 2002.

Frank, D. C., Esper, J., Raible, C. C., Büntgen, U., Trouet, V., Stocker, B., and Joos, F.: Ensemble reconstruction constraints on the global carbon cycle sensitivity to climate, Nature, 463, 52730, doi:10.1038/nature08769, 2010.

Fung, I., Rayner, P., and Friedlingstein, P.: Full-form earth system models: Coupled carbon-climate interaction experiment (the flying leap), IGBP Global Change Newslet., 41, 7-8, 2000.

Ganopolski, A., Kubatzki, C., Claussen, M., Brovkin, V., and Petoukhov, V.: The influence of vegetation-atmosphere-ocean interaction on climate during the mid-Holocene, Science, 280, 1916-1919, doi:10.1126/science.280.5371.1916, 1998.

Gao, C., Robock, A., and Ammann, C.: Volcanic forcing of climate over the past 1500 years: An improved ice corebased index for climate models, J. Geophys. Res., 113, 1-15, doi:10.1029/2008JD010239, 2008.

Gerber, S., Joos, F., Brugger, P., Stocker, T., Mann, M., Sitch, S., and Scholze, M.: Constraining temperature variations over the last millennium by comparing simulated and observed atmospheric $\mathrm{CO}_{2}$, Clim. Dynam., 20, 281-299, doi:10.1007/s00382002-0270-8, 2003.

González-Rouco, F.: Deep soil temperature as proxy for surface air-temperature in a coupled model simulation of the last thousand years, Geophys. Res. Lett., 30, 1-4, doi:10.1029/2003GL018264, 2003.

Goosse, H.: Modelling the climate of the last millennium: What causes the differences between simulations?, Geophys. Res. Lett., 32, 2-5, doi:10.1029/2005GL022368, 2005.

Hansen, J. and Sato, M.: Greenhouse gas growth rates, P. Natl. Acad. Sci. USA, 101, 16109-16114, 2004.

Hargreaves, J. C., Annan, J. D., Yoshimori, M., and Abe-Ouchi, A.: Can the Last Glacial Maximum constrain climate sensitivity? Geophys. Res. Lett., 39, L24702 doi:10.1029/2012GL053872, 2012.

Harrison, S. P. and Prentice, C. I.: Climate and $\mathrm{CO}_{2}$ controls on global vegetation distribution at the last glacial maximum: analysis based on palaeovegetation data, biome modelling and palaeoclimate simulations, Global Change Biol., 9, 983-1004, 
doi:10.1046/j.1365-2486.2003.00640.x, 2003.

Harrison, S. P., Yu, G., Takahara, H., and Prentice, I. C.: Palaeovegetation. Diversity of temperate plants in east Asia, Nature, 413, 129-130, doi:10.1038/35093166, 2001.

Harrison, S., Kutzbach, J., Liu, Z., and Bartlein, P.: Mid-Holocene climates of the Americas?: a dynamical response to changed seasonality, Clim. Dynam., 20, 663-688, doi:10.1007/s00382-0020300-6, 2003.

Hasumi, H.: CCSR Ocean Component Model (COCO) Version 2.1, CCSR Report, 13, 68 pp., 2000.

Hoelzmann, P., Jolly, D., Harrison, S. P., Laarif, F., Bonnefille, R., and Pachur, H.-J.: Mid-Holocene land-surface conditions in northern Africa and the Arabian Peninsula: A data set for the analysis of biogeophysical feedbacks in the climate system, Global Biogeochem. Cy., 12, (1), 35-51, doi:10.1029/97GB02733, 1998.

Hunke, E. C. and Dukowicz, J. K.: An Elastic-Viscous-Plastic Model for Sea Ice Dynamics, J. Phys. Ocean., 27, 1849-1867, doi:10.1175/1520-0485(1997)027<1849:AEVPMF>2.0.CO;2, 1997.

IPCC Fourth Assessment Report: Climate Change 2007, edited by: Solomon, S., Qin, D., Manning, M., Chen, Z., Marquis, M., Averyt, K. B., Tignor, M., and Miller, H. L., Intergovernmental Panel on Climate Change, 2007.

Ise, T., Hajima, T., Sato, H., and Kato, T.: Simulating the twoway feedback between terrestrial ecosystems and climate: Importance of forest ecological processes on global change, in: Forest Canopies: Forest Production, Ecosystem Health, and Climate Conditions, edited by: Creighton, J. D. and Roney, P. J., NOVA, New York, 111-126, 2009.

Jolly, D., Prentice, I. C., Bonnefille, R., Ballouche, A., Bengo, M., Brenac, P., Buchet, G., Burney, D., Cazet, J.-P., Cheddadi, R., Edorh, T., Elenga, H., Elmoutaki, S., Guiot, J., Laarif, F., Lamb, H., Lezine, A.-M., Maley, J., Mbenza, M., Peyron, O., Reille, M., Reynaud-Farrera, I., Riollet, G., Ritchie, J. C., Roche, E., Scott, L., Ssemmanda, I., Straka, H., Umer, M., Van Campo, E., Vilimumbalo, S., Vincens, A. and Waller, M.: Biome reconstruction from pollen and plant macrofossil data for Africa and the Arabian peninsula at 0 and 6000 years, J. Biogeogr., 25, 1007-1027, doi:10.1046/j.1365-2699.1998.00238.x, 1998.

Joos, F.: Reconstructed evolution of $\mathrm{CO}_{2}, \mathrm{CH}_{4}, \mathrm{~N}_{2} \mathrm{O}$ over past 2 millennia, available at: https://wiki. lsce.ipsl.fr/pmip3/lib/exe/fetch.php/pmip3:design:lm: ghg_lawdome_giss_merge_c5mip_24ju109.1-2000.txt,

last accessed: 30 May 2013, 2007.

Joos, F. and Spahni, R.: Rates of change in natural and anthropogenic radiative forcing over the past 20000 years, P. Natl. Acad. Sci. USA, 105, 1425-1430, 2008.

Joussaume, S., Taylor, K. E., Braconnot, P., Mitchell, J. F. B., Kutzbach, J. E., Harrison, S. P., Prentice, I. C., Broccoli, A. J., Abe-Ouchi, A., Bartlein, P. J., Bonfils, C., C., Dong, B., Guiot, J., Herterich, K., Hewitt, C. D., Jolly, D., Kim, J. W., Kislov, A., Kitoh, A., Loutre, M. F., Masson, V., McAvaney, B., McFarlane, N., de Noblet, N., Peltier, W. R., Peterschmitt, J. Y., Pollard, D., Rind, D., Royer, J. F., Schlesinger, M. E., Sytkus, J., Thompson, S., Valdes, P., Vettoretti, G., Webb, R. S., and Wyputta, U.: Monsoon changes for 6000 years ago: Results of 18 simulations from the Paleoclimate Modeling Intercomparison Project (PMIP), Geophys. Res. Lett., 26, 859-862,
doi:10.1029/1999GL900126, 1999.

Jungclaus, J. H., Lorenz, S. J., Timmreck, C., Reick, C. H., Brovkin, V., Six, K., Segschneider, J., Giorgetta, M. A., Crowley, T. J., Pongratz, J., Krivova, N. A., Vieira, L. E., Solanki, S. K., Klocke, D., Botzet, M., Esch, M., Gayler, V., Haak, H., Raddatz, T. J., Roeckner, E., Schnur, R., Widmann, H., Claussen, M., Stevens, B., and Marotzke, J.: Climate and carbon-cycle variability over the last millennium, Clim. Past, 6, 723-737, doi:10.5194/cp-6723-2010, 2010.

K-1 model developers: K-1 Coupled GCM (MIROC) Description, K-1 Technical Report No.1, Center for Climate System Research (Univ. of Tokyo), National Institute for Environmental Studies, and Frontier Research Center for Global Change, available at: http://www.ccsr.u-tokyo.ac.jp/kyosei/hasumi/MIROC/ tech-repo.pdf (last access: 30 March 2012), 2004.

Kohfeld, K. E. and Harrison, S. P.: How well can we simulate past climates? Evaluating the models using global palaeoenvironmental datasets, Quaternary Sci. Rev., 19, 321-346, doi:10.1016/S0277-3791(99)00068-2, 2000.

Kohfeld, K. E. and Ridgwell, A.: Glacial-interglacial variability in atmospheric $\mathrm{CO}_{2}$, Surface Ocean-Lower Atmosphere Processes, Geophysical Research Series 37, Washington DC, American Geophysical Union, 251-286, 2009.

Laîné, A., Kageyama, M., Braconnot P., and Alkama, R.: Impact of greenhouse gas concentration changes on the surface energetics in the IPSL-CM4 model: Regional warming patterns, land/sea warming ratio, glacial/interglacial differences, J. Climate, 22, 4621-4635, doi:10.1175/2009JCLI2771.1, 2009.

Lambeck, K. and Chappell, J.: Sea level change through the last glacial cycle, Science, 292, 679-686, doi:10.1126/science.1059549, 2001.

Lambeck, K. and Yokoyama, Y.: Into and out of the Last Glacial Maximum: sea-level change during Oxygen Isotope Stages 3 and 2, Quaternary Sci. Rev., 21, 343-360, doi:10.1016/S02773791(01)00071-3, 2002.

Lambeck, K., Purcell, A., Johnston, P., Nakada, M., and Yokoyama, Y: Water-load definition in the glacio-hydroisostatic sea-level equation, Quaternary Sci. Rev., 22, 309-318, doi:10.1016/S0277-3791(02)00142-7, 2003.

Lean, J.: Evolution of the Sun's Spectral Irradiance Since the Maunder Minimum, Geophys. Res. Lett., 27, 2425, doi:10.1029/2000GL000043, 2000 .

Levis, S., Bonan, G. B. and Bonfils, C.: Soil feedback drives the mid-Holocene North African monsoon northward in fully coupled CCSM2 simulations with a dynamic vegetation model, Clim. Dynam., 23, 791-802, doi:10.1007/s00382-004-0477-y, 2004.

Levitus, S., Boyer, T. P., Conkright, M. E., O’Brien, T., Antonov, J., Stephens, C., Stathoplos, L., Johnson, D., and Gelfeld, R.: World Ocean Database 1998, vol. 1, Introduction. NOAA Atlas NESDIS 18 (US Government Printing Office, Washington, DC,) 1998.

Liu, Z., Brady, E., and Lynch-Stieglitz, J.: Global ocean response to orbital forcing in the Holocene, Paleoceanography, 18, 1-20, doi:10.1029/2002PA000819, 2003

MacFarling Meure, C. M., Etheridge, D., Trudinger, C., Steele, P., Langenfelds, R., Van Ommen, T., Smith, A., and Elkins, J.: Law Dome $\mathrm{CO}_{2}, \mathrm{CH}_{4}$ and $\mathrm{N}_{2} \mathrm{O}$ ice core records extended to 2000 years BP, Geophys. Res. Lett., 33, L14810, 
doi:10.1029/2006GL026152, 2006.

Machida, T., Nakazawa, T., Fujii, Y., Aoki, S., and Watanabe, O.: Increase in the Atmospheric Nitrous-Oxide Concentration during the Last 250 Years, Geophys. Res. Lett., 22, 2921-2924, 1995.

Mann, M. E., Zhang, Z., Rutherford, S., Bradley, R. S., Hughes, M. K., Shindell, D., Ammann, C. M., Faluvegi, G., and Ni, F.: Global signatures and dynamical origins of the Little Ice Age and Medieval Climate Anomaly, Science, 326, 1256-1260, doi:10.1126/science.1177303, 2009.

Mann, M. E., Fuentes, J. D., and Rutherford, S.: Underestimation of volcanic cooling in tree-ring-based reconstructions of hemispheric temperatures, Nat. Geosci., 5, 202-205, doi:10.1038/ngeo1394, 2012

Marchant, R., Cleef, A., Harrison, S. P., Hooghiemstra, H., Markgraf, V., van Boxel, J., Ager, T., Almeida, L., Anderson, R., Baied, C., Behling, H., Berrio, J. C., Burbridge, R., Björck, S., Byrne, R., Bush, M., Duivenvoorden, J., Flenley, J., De Oliveira, P., van Geel, B., Graf, K., Gosling, W. D., Harbele, S., van der Hammen, T., Hansen, B., Horn, S., Kuhry, P., Ledru, M.P., Mayle, F., Leyden, B., Lozano-García, S., Melief, A. M., Moreno, P., Moar, N. T., Prieto, A., van Reenen, G., SalgadoLabouriau, M., Schäbitz, F., Schreve-Brinkman, E. J., and Wille, M.: Pollen-based biome reconstructions for Latin America at 0, 6000 and 18000 radiocarbon years ago, Clim. Past, 5, 725-767, doi:10.5194/cp-5-725-2009, 2009.

MARGO Project Members: Constraints on the magnitude and patterns of ocean cooling at the Last Glacial Maximum, Nat. Geosci., 2, 127-132, doi:10.1038/ngeo411, 2009.

McManus, J. F., Francois, R., Gherardi, J.-M., Keigwin, L. D., and Brown-Leger, S.: Collapse and rapid resumption of Atlantic meridional circulation linked to deglacial climate changes., Nature, 428, 834-837, doi:10.1038/nature02494, 2004.

Murakami, S., Ohgaito, R., Abe-Ouchi, A., Crucifix, M., and OttoBliesner, B. L.: Global-Scale Energy and Freshwater Balance in Glacial Climate: A Comparison of Three PMIP2 LGM Simulations, J. Climate, 21, 5008-5033, doi:10.1175/2008JCLI2104.1, 2008.

Nozawa, T., Nagashima, T., Yokohata, T., Okada, N., and Shiogama, H.: Climate Change Simulations with a Coupled Ocean-Atmosphere GCM Called the Model for Interdisciplinary Research on Climate?, MIROC Center for Global Environmental Research National Institute for Environmental Studies, Tsukuba, Japan, available at: http://www.cger.nies.go.jp/ publications/report/i073/I073.pdf, 12, 82 pp., 2007.

Ohgaito, R. and Abe-Ouchi, A.: The role of ocean thermodynamics and dynamics in Asian summer monsoon changes during the mid-Holocene, Clim. Dynam., 1, 39-50, doi:10.1007/s00382006-0217-6, 2007.

Ohgaito, R. and Abe-Ouchi, A.: The effect of sea surface temperature bias in the PMIP2 AOGCMs on mid-Holocene Asian monsoon enhancement, Clim. Dynam., 33, 975-983, doi:10.1007/s00382-009-0533-8, 2009.

Ohgaito, R., Sueyoshi, T., Abe-Ouchi, A., Hajima, T., Watanabe, S., Kim, H.-J., Yamamoto, A., and Kawamiya, M.: Climate and African precipitation changes in the mid-Holocene simulated using an Earth System Model MIROC-ESM, Clim. Past Discuss., 8, 3277-3343, doi:10.5194/cpd-8-3277-2012, 2012.

Oka, A., Hasumi, H., and Abe-Ouchi, A.: The thermal threshold of the Atlantic meridional overturning circulation and its control by wind stress forcing during glacial climate, Geophys. Res. Lett., 39, 1-6, doi:10.1029/2012GL051421, 2012.

Oki, T. and Sud, Y. C.: Design of Total Runoff Integrating Pathways (TRIP) - A Global River Channel Network, Earth Interact., 2, 1-36, doi:10.1175/10873562(1998)002<0001:DoTRIP>2.0.CO;2, 1998.

Oschlies, A.: Model-derived estimates of new production: New results point towards lower values, Deep-Sea Res. Pt. II, 48, 2173 2197, doi:10.1016/S0967-0645(00)00184-3, 2001.

Oschlies, A. and Garçon, V.: An eddy-permitting coupled physicalbiological model of the North Atlantic 1. Sensitivity to advection numerics and mixed layer physics, Global Biogeochem. Cy., 13, 135-160, doi:10.1029/98GB02811, 1999.

Otto-Bliesner, B. L., Hewitt, C. D., Marchitto, T. M., Brady, E., Abe-Ouchi, A., Crucifix, M., Murakami, S., and Weber, S. L.: Last Glacial Maximum ocean thermohaline circulation: PMIP2 model intercomparisons and data constraints, Geophys. Res. Lett., 34, 1-6, doi:10.1029/2007GL029475, 2007.

Otto-Bliesner, B. L., Joussaume, S., Harrison, S. P., Abe-Ouchi, A., and Braconnot, P.: PMIP2 Workshop, PAGES news, 17, 42-43, 2009.

Paleoclimate Modelling Intercomparison Project Phase III: Ice Sheet for PMIP3/CMIP5 simulations, aavilable at: https://wiki. 1sce.ipsl.fr/pmip3/doku.php/pmip3:design:pi:final:icesheet, last access: 30 May 2013, 2010.

Peltier, W. R. and Drummond, R.: Rheological stratification of the lithosphere: A direct inference based upon the geodetically observed pattern of the glacial isostatic adjustment of the North American, Geophys. Res. Lett., 35, 1-5, doi:10.1029/2008GL034586, 2008.

Peltier, W. R., Argus, D. F., Drummond, R., Gyllencreutz, R., Mangerud, J., Swensen, J.-I., and Lohne, O. S.: Space Geodesy Constrains Ice-Age Terminal Deglaciation, Nature, submitted, 2013.

Petit, J. R., Briat, M., and Royer, A.: Ice age aerosol content from East Antarctic ice core samples and past wind strength, Nature, 293, 857-859, doi:10.1038/293391a0, 1981.

Peyron, O., Jolly, D., Braconnot, P., Bonnefille, R., Guiot, J., Wirrmann, D., and Chalié, F.: Quantitative reconstructions of annual rainfall in Africa 6000 years ago: Model-data comparison, J. Geophys. Res., 111, D24110, doi:10.1029/2006JD007396, 2006.

Pickett, E. J., Harrison, S. P., Hope, G., Harle, K., Dodson, J. R., Kershaw, A. P., Prentice, I. C., Backhouse, J., Colhoun, E. A., D'costa, D., Flenley, J., Grindrod, J., Haberle, S., Hassell, C., Kenyon, C., Macphail, M., Martin, H., Martin, A. H., Mckenzie, M., Newsome, J. C., Penny, D., Powell, J., Raine, J. I., Southern, W., Stevenson, J., Sutra, J. P., Thomas, I., Van Der Kaars, S., and Ward, J.: Pollen-based reconstructions of biome distributions for Australia, Southeast Asia and the Pacific (SEAPAC region) at 0, 6000 and 18,000 14C yr BP, J. Biogeogr., 31, 1381-1444, doi:10.1111/j.1365-2699.2004.01001.x, 2004.

Pinto, J. P., Turco, R. P., and Toon, O. B.: Self-limiting Physical and Chemical Effects in Volcanic Eruption Clouds, J. Geophys. Res., 94, 11165-11174, doi:10.1029/JD094iD08p11165, 1989.

Prentice, I. C. and Jolly, D.: Mid-Holocene and glacial-maximum vegetation geography of the northern continents and Africa, J. Biogeogr., 27, 507-519, doi:10.1046/j.1365-2699.2000.00425.x, 2000. 
Ray, N. and Adams, J. M.: A GIS-based Vegetation Map of the World at the Last Glacial Maximum (25,000-15,000 BP), Internet Archaeology, 11, 1-44, 2001.

Rojas, M., Moreno, P., Kageyama, M., Crucifix, M., Hewitt, C., Abe-Ouchi, A., Ohgaito, R., Brady, E. C., and Hope, P.: The Southern Westerlies during the last glacial maximum in PMIP2 simulations, Clim. Dynam., 32, 525-548, doi:10.1007/s00382008-0421-7, 2009.

Sato, H., Itoh, A., and Kohyama, T.: SEIB-DGVM: A new Dynamic Global Vegetation Model using a spatially explicit individual-based approach, Ecol. Model., 200, 279-307, doi:10.1016/j.ecolmodel.2006.09.006, 2007.

Sato, M., Hansen, J. E., Mccormick, M. P., and Pollack, J. B.: Stratospheric aerosol optical depths, 1850-1990, J. Geophys. Res.-Atmos., 98, 22987-22994, doi:10.1029/93JD02553, 1993.

Schmidt, G. A., Jungclaus, J. H., Ammann, C. M., Bard, E., Braconnot, P., Crowley, T. J., Delaygue, G., Joos, F., Krivova, N. A., Muscheler, R., Otto-Bliesner, B. L., Pongratz, J., Shindell, D. T., Solanki, S. K., Steinhilber, F., and Vieira, L. E. A.: Climate forcing reconstructions for use in PMIP simulations of the last millennium (v1.0), Geosci. Model Dev., 4, 33-45, doi:10.5194/gmd4-33-2011, 2011.

Schmidt, G. A., Jungclaus, J. H., Ammann, C. M., Bard, E., Braconnot, P., Crowley, T. J., Delaygue, G., Joos, F., Krivova, N. A., Muscheler, R., Otto-Bliesner, B. L., Pongratz, J., Shindell, D. T., Solanki, S. K., Steinhilber, F., and Vieira, L. E. A.: Climate forcing reconstructions for use in PMIP simulations of the Last Millennium (v1.1), Geosci. Model Dev., 5, 185-191, doi:10.5194/gmd-5-185-2012, 2012.

Schmittner, A., Urban, N. M., Shakun, J. D., Mahowald, N. M., Clark, P. U., Bartlein, P. J., Mix, A. C., and Rosell-Mele, A.: Climate Sensitivity Estimated from Temperature Reconstructions of the Last Glacial Maximum, Science, 334, 1385-1388, doi:10.1126/science.1203513, 2011.

Semtner, A. J.: A Model for the Thermodynamic Growth of Sea Ice in Numerical Investigations of Climate, J. Phys. Ocean., 6, 379-389, doi:10.1175/15200485(1976)006<0379:AMFTTG>2.0.CO;2, 1976.

Servonnat, J., Yiou, P., Khodri, M., Swingedouw, D., and Denvil, S.: Influence of solar variability, $\mathrm{CO}_{2}$ and orbital forcing between 1000 and $1850 \mathrm{AD}$ in the IPSLCM4 model, Clim. Past, 6, 445460, doi:10.5194/cp-6-445-2010, 2010.

Shindell, D. T., Schmidt, G. A., Mann, M. E., Rind, D., and Waple, A.: Solar forcing of regional climate change during the Maunder Minimum, Science, 294, 2149-2152, doi:10.1126/science.1064363, 2001.

Takata, K., Emori, S., and Watanabe, T.: Development of the minimal advanced treatments of surface interaction and runoff, Global Planet. Change, 38, 209-222, doi:10.1016/S09218181(03)00030-4, 2003.

Takemura, T.: Simulation of climate response to aerosol direct and indirect effects with aerosol transport-radiation model, J. Geophys. Res., 110, D02202, doi:10.1029/2004JD005029, 2005.

Takemura, T., Okamoto, H., Maruyama, Y., Numaguti, A., Higurashi, A., and Nakajima, T.: Global three-dimensional simulation of aerosol optical thickness distribution of various origins, J. Geophys. Res., 105, 17853-17873, doi:10.1029/2000JD900265, 2000 .
Takemura, T., Nakajima, T., Dubovik, O., Holben, B. N., and Kinne, S.: Single-Scattering Albedo and Radiative Forcing of Various Aerosol Species with a Global ThreeDimensional Model, J. Climate, 15, 333-352, doi:10.1175/15200442(2002)015<0333:SSAARF>2.0.CO;2, 2002.

Tans, P. and Keeling, R.: Trends in Atmospheric Carbon Dioxide, available at: http://www.esrl.noaa.gov/gmd/ccgg/trends/, last access: 30 March 2012.

Tarasov, L. and Peltier, W. R.: Greenland glacial history and local geodynamic consequences, Geophys. J. Int., 150, 198-229, doi:10.1046/j.1365-246X.2002.01702.x, 2002.

Tarasov, L. and Peltier, W. R.: Greenland glacial history, borehole constraints, and Eemian extent, J. Geophys. Res, 108, 1-20, doi:10.1029/2001JB001731, 2003.

Tarasov, P. E., Volkova, V. S., Webb, T., Guiot, J., Andreev, A. A., Bezusko, L. G., Bezusko, T. V., Bykova, G. V., Dorofeyuk, N. I., Kvavadze, E. V., Osipova, I. M., Panova, N. K., and Sevastyanov, D. V.: Last glacial maximum biomes reconstructed from pollen and plant macrofossil data from northern Eurasia, J. Biogeogr., 27, 609-620, doi:10.1046/j.1365-2699.2000.00429.x, 2000.

Taylor, K. E., Stouffer, R. J., and Meehl, G. A.: A summary of the CMIP5 experimental design, with updates/corrections in 2011, available at: http://cmip-pcmdi.llnl.gov/cmip5/docs/ Taylor_CMIP5_design.pdf, (last access: 30 May 2013), 2009.

Taylor, K. E., Stouffer, R. J., and Meehl, G. A.: An Overview of CMIP5 and the Experiment Design, B. Am. Meteorol. Soc., 93, 485-498, doi:10.1175/BAMS-D-11-00094.1, 2012.

Toracinta, E. R., Oglesby, R. J., and Bromwich, D. H.: Atmospheric Response to Modified CLIMAP Ocean Boundary Conditions during the Last Glacial Maximum, J. Climate, 17, 504-522, doi:10.1175/1520-0442(2004)017<0504:ARTMCO > 2.0.CO;2, 2004.

Trouet, V., Esper, J., Graham, N. E., Baker, A., Scourse, J. D., and Frank, D. C.: Persistent positive North Atlantic Oscillation mode dominated the medieval climate anomaly, Science, 324, p. 78, 2009.

Wang, Y.-M., Lean, J. L., and Sheeley Jr., N. R.: Modeling the Sun's Magnetic Field and Irradiance since 1713, Astrophys. J., 625, 522-538, doi:10.1086/429689, 2005.

Watanabe, S., Miura, H., and Sekiguchi, M.: Development of an atmospheric general circulation model for integrated Earth system modeling on the Earth Simulator, J. Earth Simulator, 9, 27-35, 2008.

Watanabe, S., Hajima, T., Sudo, K., Nagashima, T., Takemura, T., Okajima, H., Nozawa, T., Kawase, H., Abe, M., Yokohata, T., Ise, T., Sato, H., Kato, E., Takata, K., Emori, S., and Kawamiya, M.: MIROC-ESM 2010: model description and basic results of CMIP5-20c3m experiments, Geosci. Model Dev., 4, 845-872, doi:10.5194/gmd-4-845-2011, 2011.

Weber, S. L., Drijfhout, S. S., Abe-Ouchi, A., Crucifix, M., Eby, M., Ganopolski, A., Murakami, S., Otto-Bliesner, B., and Peltier, W. R.: The modern and glacial overturning circulation in the Atlantic ocean in PMIP coupled model simulations, Clim. Past, 3, 51-64, doi:10.5194/cp-3-51-2007, 2007.

World Ocean Atlas: Tech. rep., National Oceanographic Data Center, Silver Spring, Maryland, available at: http://www.nodc.noaa. gov/OC5/indpub.html\#World\%20Ocean\%20Atlas\%201998, (last access: 7 June 2013), Version 2, 1998. 
Xie, P. and Arkin, P. A.: Analyses of global monthly precipitation using gauge observations, satellite estimates, and numerical model predictions, J. Climate, 9, 840-858, doi:10.1175/15200442(1996)009<0840:AOGMPU>2.0.CO;2, 1996.

Yang, Z.-L., Dickinson, R. E., Robock, A. and Vinnikov, K. Y.: Validation of the Snow Submodel of the Biosphere-Atmosphere Transfer Scheme with Russian Snow Cover and Meteorological Observational Data, J. Climate, 10, 353-373, doi:10.1175/15200442(1997)010<0353:VOTSSO > 2.0.CO;2, 1997.

Yin, J. H. and Battisti, D. S.: The Importance of Tropical Sea Surface Temperature Patterns in Simulations of Last Glacial Maximum Climate, J. Climate, 14, 565-581, doi:10.1175/15200442(2001)014<0565:TIOTSS>2.0.CO;2, 2001.

Yu, G. , Chen, X. , Ni, J., Cheddadi, R., Guiot, J., Han, H., Harrison, S. P., Huang, C., Ke, M., Kong, Z., Li, S., Li, W., Liew, P., Liu, G., Liu, J., Liu, Q., Liu, K.-B., Prentice, I. C., Qui, W., Ren, G., Song, C., Sugita, S., Sun, X., Tang, L., Van Campo, E., Xia, Y., Xu, Q., Yan, S., Yang, X., Zhao, J., and Zheng, Z.: Palaeovegetation of China: a pollen data-based synthesis for the mid-Holocene and last glacial maximum, J. Biogeogr., 27, 635664, doi:10.1046/j.1365-2699.2000.00431.x, 2000.
Zhao, Y. and Harrison, S. P.: Mid-Holocene monsoons: a multimodel analysis of the inter-hemispheric differences in the responses to orbital forcing and ocean feedbacks, Clim. Dynam., doi:10.1007/s00382-011-1193-z, 39, 1457-1487, 2011.

Zhao, Y., Braconnot, P., Marti, O., Harrison, S. P., Hewitt, C., Kitoh, A., Liu, Z., Mikolajewicz, U., Otto-Bliesner, B., and Weber, S. L.: A multi-model analysis of the role of the ocean on the African and Indian monsoon during the mid-Holocene, Clim. Dynam., 25, 777-800, doi:10.1007/s00382-005-0075-7, 2005.

Zhao, Y., Braconnot, P., Harrison, S. P., Yiou, P., and Marti, O.: Simulated changes in the relationship between tropical ocean temperatures and the western African monsoon during the midHolocene, Clim. Dynam., 28, 533-551, doi:10.1007/s00382006-0196-7, 2007.

Zhong, Y., Miller, G. H., Otto-Bliesner, B. L., Holland, M. M., Bailey, D. A., Schneider, D. P., and Geirsdottir, A.: Centennialscale climate change from decadally-paced explosive volcanism: a coupled sea ice-ocean mechanism, Clim. Dynam., 37, 2373 2387, doi:10.1007/s00382-010-0967-z, 2011. 